\title{
EVALUATION OF FUEL IMPURITY EFFECTS ON SOLID OXIDE FUEL CELL PERFORMANCE
}

Final Technical Report

April 1998

Contract DE-AC21-89MC26355--02

S. E. Veyo, Project Manager

Westinghouse Electric Company

a Subsidiary of CBS Corporation

Science \& Technology Center

SOFC Power Generation

1310 Beulah Road

Pittsburgh, PA 15235 


\section{NOTICE}

This report was prepared as an account of work sponsored by an agency of the U nited States Government. Neither the Untied States Government nor any agency thereof, nor any of their employees, makes any warranty, express or implied, or assumes any legal liability or responsibility for the accuracy, completeness, or usefulness of any information, apparatus, product, or process disclosed, or represents that its use would not infringe privately owned rights. Reference herein to any specific commercial product, process, or service by trade name, trademark, manufacturer, or otherwise does not necessarily constitute or imply its endorsement, recommendation, or favoring by the United States Government or any agency thereof. The views and opinions of authors expressed herein do not necessarily state or reflect those of the United States Government or any agency thereof.

Available to the public from the National Technical Information Service, U.S. Department of Commerce, 5285 Port Royal Road, Springfield, VA 22161; phone orders accepted at (703) 487-4650. 


\begin{abstract}
The effects of various fuel and air impurities on the performance of tubular solid oxide fuel cells have been examined. Two-cell SOFC tests were conducted using simulated coal gas contaminated with 1 ppm $\mathrm{H}_{2} \mathrm{~S}, 1$ ppm $\mathrm{HCl}$, and 5000 ppm $\mathrm{NH}_{3}$. Of these only $\mathrm{H}_{2} \mathrm{~S}$ was found to have a significant effect. Another two-cell test was conducted in which the effect of $\mathrm{SiO}_{2}$ carryover into fuel electrode was examined. Testing was also conducted to investigate the effects of copper on nickel containing cell components. Three different air impurities were examined. Single cell testing was performed using air contaminated with sulfur dioxide, with extremely high levels of water vapor, with water vapor and sulfur dioxide, and with sea water mist.
\end{abstract}




\section{CONTENTS}

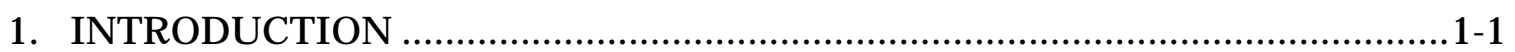

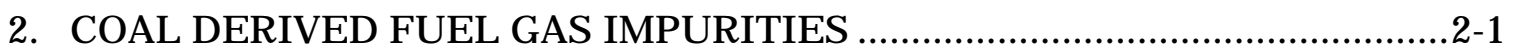

2.1 Objectives ................................................................................................

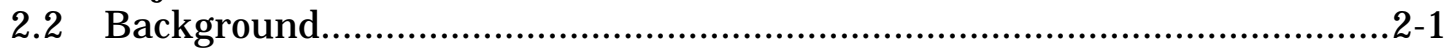

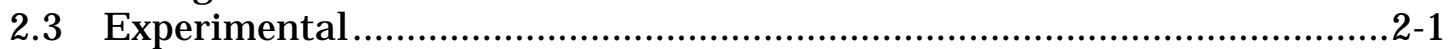

2.4 Results and Discussion....................................................................... 2-3

2.4.1 Extended SOFC Testing at $1000^{\circ} \mathrm{C}$ with $\mathrm{NH}_{3}, \mathrm{HCl}$, and

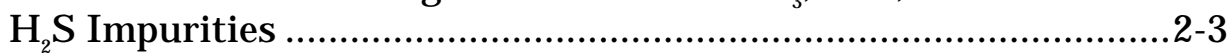

2.4.2 SOFC Testing at $1025^{\circ} \mathrm{C}$ with $\mathrm{NH}_{3}, \mathrm{HCl}$, and $\mathrm{H}_{2} \mathrm{~S}$ I mpurities........2-3

2.4.3 Follow-On Long Term SOFC Testing at $1000^{\circ} \mathrm{C}$...........................2-7

2.4.4 Overall Performance Loss in the Presence of $\mathrm{NH}_{3}, \mathrm{HCl}$ and $\mathrm{H}_{2} \mathrm{~S}$...2-7

2.4.5 Initial Test at $1000^{\circ} \mathrm{C}$ and $350 \mathrm{~mA} / \mathrm{cm}^{2}$ Using Coal-Derived Fuel Gas with Silicon Impurity................................................2-10

2.4.6 Short-Term SOFC Testing at $1000^{\circ} \mathrm{C}$ and $350 \mathrm{~mA} / \mathrm{cm}^{2}$ Using Simulated Partially Reformed Natural Gas......................2-10

2.4.7 Silicon Carryover as a Fuel Contaminant...................................2-14

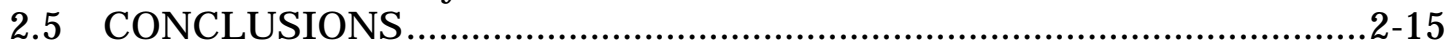

3. ADDITIONAL CELL COMPONENT IMPURITIES ….....................................

3.1 Objectives ...................................................................................

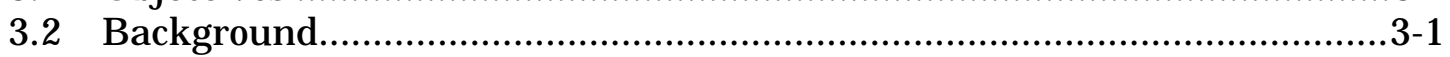

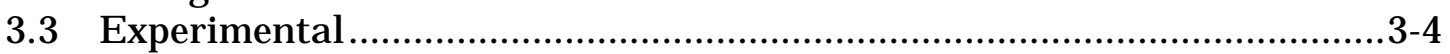

3.4 Results and Discussion................................................................

3.4.1 Densification of the fuel electrode: ............................................3-10

3.4.2 Absence of copper bond layer:................................................. $3-14$

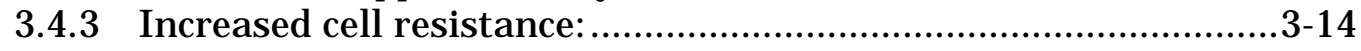

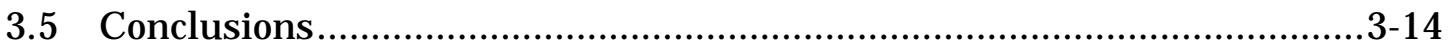

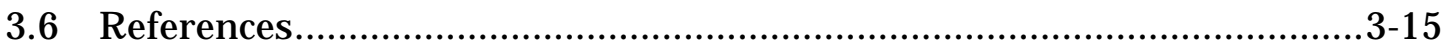

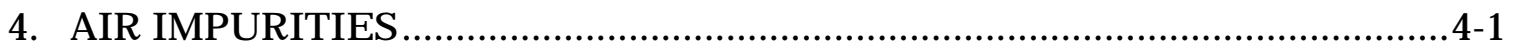

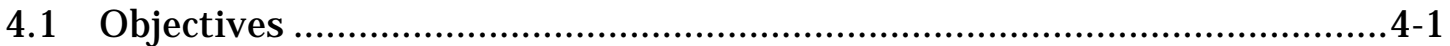

4.2 Background................................................................................

4.3 Experimental ..............................................................................

4.4 Results and Discussion........................................................................ $4-8$

4.5 Conclusions ........................................................................... 4-19

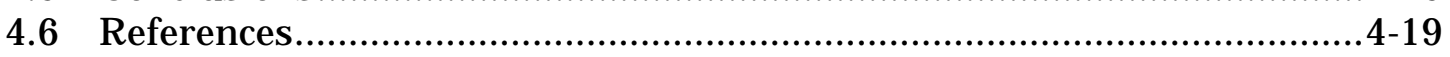




\section{LIST OF FIGURES}

Figure 2.1 - SOFC performance at $1000^{\circ} \mathrm{C}$ and $350 \mathrm{~mA} / \mathrm{cm}^{2}, 85 \%$ fuel utilization and $25 \%$ air utilization. Fuel $=$ simulated air-blown coal gas Table 1)......2-4

Figure 2.2 - SOFC performance at $1025^{\circ} \mathrm{C}$ and $350 \mathrm{~mA} / \mathrm{cm} 2,85 \%$ fuel utilization and $25 \%$ air utilization. Fuel $=$ simulated air-blown coal gas containing 5000 ppm N H3, 1 ppm HCl and 1 ppm $\mathrm{H}_{2} \mathrm{~S} \ldots \ldots \ldots \ldots \ldots . . .2-6$

Figure 2.3 - SOFC performance at $1000^{\circ} \mathrm{C}$ and $350 \mathrm{~mA} / \mathrm{cm}^{2}, 85 \%$ fuel utilization and $25 \%$ air utilization. Fuel $=$ simulated air-blown coal gas containing $5000 \mathrm{ppm} \mathrm{NH}_{3}, 1 \mathrm{ppm} \mathrm{HCl}$ and $0.1 \mathrm{ppm} \mathrm{H}_{2} \mathrm{~S}$

Figure 2.4 - Location of silicon-rich areas at exposed nickel network of SOFC fuel electrode, after approximately 2,400 hours of operation at $1000^{\circ} \mathrm{C}$ in simulated coal gas $\left(13 \% \mathrm{H}_{2} \mathrm{O}\right)$ with $\mathrm{Si}$ impurity.

Figure $2.5-\mathrm{SOFC}$ performance at $1000^{\circ} \mathrm{C}$ and $350 \mathrm{~mA} / \mathrm{cm}^{2}, 85 \%$ fuel utilization and $25 \%$ air utilization. Fuel containing 1) $11 \% \mathrm{H}_{2} \mathrm{O}$, 2) $26.2 \% \mathrm{H}_{2} \mathrm{O}$ (Fuel A), 3) $56.7 \% \mathrm{H}_{2} \mathrm{O}$ (Fuel B) passing over silica, $\mathrm{SiO}_{2} \ldots 2-13$

Figure 3.1 - Cu-Ni binary alloy phase diagram (1). A continuous solid solution formation is indicated.

Figure 3.2 - Schematic representation of the Kirkendall effect with "cavity and swelling formation" appearing in the neighborhood of the phase boundary in the nickel-copper system, according to Seith and Kottmann...3-5

Figure 3.3 - Morphology of copper powder used for bonding experiments. EDS analysis of the powder shows the presence of copper only.

Figure 3.4 - Electrical performance of cell \#577. Cell shows stable voltage and resistance.

Figure 3.5 - Electrical performance of cell \#578. Cell shows declining voltage and increase in resistance.

Figure 3.6 - Cell from cell test \#578. Separation of cell and felt near the closed end is observed.

Figure 3.7 - Densification of fuel electrode due to diffusion of copper.

Figure 3.8- Elemental distribution in the fuel electrode. Fuel el ectrode shows copper throughout the thickness and an absence of a discrete copper layer.3-12

Figure 3.9 - Porous fuel el ectrode structure obtained at $90^{\circ}$ from the $\mathrm{Cu}$ contact area.

Figure 4.1 - Illustration of the air delivery system used for testing with gaseous impurities.

Figure 4.2 - Photograph showing set up of the seawater bubbler. 
Figure 4.3- Cell voltage and resistance data from testing with gaseous impurities ( 0 to 2200 hours elapsed time).

Figure 4.4 - Voltage versus current density curves comparing cell performance on dry and humidified air....

Figure 4.5 - Cell voltage and resistance data from testing with air containing sea water mist (2200 to 3300 hours elapsed time).

Figure 4.6 - Voltage versus current density curves comparing cell performance on air containing sea water mist with that of dry air.

Figure 4.7 - Voltage versus current curve comparing cell performance on dry air early in the test to that at the end of the test.

Figure 4.8 - Photograph showing air exit region of the air feed tube used during sea water mist testing. Notch at end of tube was cut prior to use.4-17

Figure 4.9- EBMA elemental maps for $\mathrm{Zr}, \mathrm{Si}$, and La showing the air electrode/electrolyte interface at three different positions on the cell. Values in $\mathrm{cm}$ refer to actual distance to the cell closed end.

\section{LIST OF TABLES}

Table 2.1- Simulated $\mathrm{O}_{2}$-Blown Coal Gas

Table 2.2 - Simulated Partially Reformed Natural Gas

Table 2.3 - Effect of Three Impurities on SOFC Operation at $1000^{\circ} \mathrm{C}$ and 350 $\mathrm{mA} / \mathrm{cm}^{2}$ (From Figure 2.1).

Table 3.1 - Physical and Chemical Properties of Nickel and Copper ......................3-2

Table 4.1 - EPA Regulated Air Pollutants.

Table 4.2 - Composition of Sea Salt Used in Sea Water Mist Experiments.

Table 4.3 - Duration of Testing with Different I mpurities 4-8 


\section{EXECUTIVE SUMMARY}

Air electrode supported solid oxide fuel cells (SOFCs) were operated at $1000^{\circ} \mathrm{C}$ and a nominal $350 \mathrm{~mA} / \mathrm{cm}^{2}$ current density to determine the effect of coalderived impurities on the electrical performance. In this work the effect of three impurities in combination, $\mathrm{NH}_{3}, \mathrm{HCl}$, and $\mathrm{H}_{2} \mathrm{~S}$, and the effect of the single impurity, silicon, were examined. The fuel gas employed in the testing represents the product obtainable from a Texaco Entrained-Bed oxygen blown coal gasifier at $776^{\circ} \mathrm{F}$ after external desulfurization.

After establishing a base line electrical performance, impurities were sequentially added to the simulated coal gas fuel. The addition of $5000 \mathrm{ppm} \mathrm{NH}_{3}$ had no adverse effects on SOFC operation during 2500 hours of testing. The $\mathrm{NH}_{3}$ may actually act as fuel and increase the cell voltage. The addition of $1 \mathrm{ppm} \mathrm{HCl}$ did not have a detectable effect, but the addition of $1 \mathrm{ppm} \mathrm{H}_{2} \mathrm{~S}$ resulted in a $60 \mathrm{mV}$ drop in cell voltage during the first 24 hours and a declining slope in the voltage versus time curve thereafter. On removal of the $\mathrm{H}_{2} \mathrm{~S}$ from the fuel, most of the lost voltage was recovered, but there was some permanent loss due to an irreversible increase in cell resistance. Further testing found that $\mathrm{H}_{2} \mathrm{~S}$ impurities at $0.1 \mathrm{ppm}$ could be tolerated with no irreversible voltage loss.

To examine the effect of silicon impurities on cell performance, the simulated coal gas fuel $\left(13.2 \% \mathrm{H}_{2} \mathrm{O}\right)$ was passed through a porous aluminosilicate insulation board composed of $74 \% \mathrm{Al}_{2} \mathrm{O}_{3}$ and $26 \% \mathrm{SiO}_{2}$. The mechanism for silicon transport is thought to be related to the reaction of silica with water vapor. Analysis of the fuel electrode after testing found some silicon accumulation on exposed nickel, but this was apparently insufficient to affect performance since no degradation was observed during testing. In subsequent tests, partially reformed natural gas fuel with higher water contents (26.2\% and $56.7 \%$ ) was used. The higher water levels appeared to enhance silicon deposition in the fuel electrode as reflected by increases in cell resistance. 
A need to develop low temperature sintering/bonding aids for attaching nickel felts to solid oxide fuel cell (SOFC) assemblies was identified. Based on the literature review and sintering characteristics of copper powder at elevated temperatures representative of the SOFC generator, it was decided to evaluate the long term structural stability of copper in contact with fuel cell components as a sintering/bonding material for attaching nickel felts. Cell-nickel felt assemblies were subsequently fabricated using copper based copper-epoxy slurry in contact with the interconnection and fuel electrode. Cells were electrically tested for more than 800 hours at $1000^{\circ} \mathrm{C}$ under normal fuel cell operating conditions.

After completion of the electrical test and during the disassembly of the test apparatus, it was observed that the contact surface appeared bright silvery and did not show the presence of copper color. Microstructure indicated densification of the cell fuel electrode which remained in contact with the copper layer. EDS analysis of the fuel electrode and the nickel el ectroplated layer showed the presence of copper throughout the thickness of the fuel electrode.

Loss of adhesion of the nickel felt from the cell interconnection and fuel electrode is postulated to be due to the bulk migration of copper from the interfacial layer into the adjacent nickel felts and cell components during the long term high temperature cell test. Relatively higher diffusion of copper in nickel leads to the migration of copper away from the bonding layer and formation of porosity at the interface (Kirkendall effect). Diffusion of copper in the fuel electrode also increases the total volume of the fuel el ectrode material and reduces the porosity of the structure. Increase in the fuel el ectrode volume and density stresses and cracks the zirconia skeleton initially formed on the surface.

It is concluded that although copper remains thermo-chemically stable in the fuel gas environment of the SOFC and that the copper-nickel solid solution formed due to the interdiffusion of nickel and copper also remains chemically stable, long term contact of copper with nickel bearing SOFC components leads to permanent structural changes. 
Additional experiments were performed to assess the effects of air impurities on the performance of SOFCs. In a review of common air pollutants three different species were identified which were considered to have a potentially deleterious impact on SOFC performance: sulfur dioxide, water vapor, and sea water mist. A single cell test was conducted at $1000^{\circ} \mathrm{C}$ and $250 \mathrm{~mA} / \mathrm{cm}^{2}$ using a $2.2 \mathrm{~cm}$ diameter, $50 \mathrm{~cm}$ active length cell. The cell was operated under five different air impurity conditions: (1) $89 \%$ dry air and $11 \%$ water vapor, (2) dry air with $0.25 \mathrm{ppm} \mathrm{SO}_{2^{\prime}}$ (3)

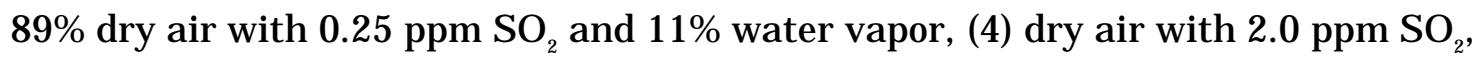
and (5) air with sea water mist.

Operation of the SOFC on humidified air (11\% water vapor) resulted in a voltage loss of $\sim 10 \mathrm{mV}$. This effect was instantaneous, and on returning to dry air operation the SOFC quickly recovered all of its lost voltage. In actual generators operating in humid environments, the performance losses should be somewhat less, and no long term problems are anticipated. During operation with sulfur dioxide impurities no voltage losses were observed at concentrations up to $2.0 \mathrm{ppm}$ which is greater than 14 times the E. P.A. ambient air quality limit. While operating with air containing sea water mist some voltage losses were observed, but these could be entirely attributed to water vapor. Most all of the salt passed through the cell with only minimal deposition on the inside diameter of the air electrode. In an actual generator the salt is expected to have greater effects on the metal components of the generator's air delivery system than on the SOFCs themselves.

A comparison of voltage versus current density curves found that over the course of the testing some performance loss had occurred. At $250 \mathrm{~mA} / \mathrm{cm}^{2}$ the voltage degradation was only $\sim 5 \mathrm{mV}$, but at $400 \mathrm{~mA} / \mathrm{cm}^{2}$ the degradation was almost $90 \mathrm{mV}$. Microcharacterization of the cell discovered a thin layer of silicon rich material at the air electrode/electrolyte interface. This layer was confined to the closed end half of the cell which experiences higher current flow than the open end. The source of the silicon was determined to be the silicone rubber tubing which was used to connect the cell's air feed tube with the air supply. Therefore, the air 
impurities were not directly responsible for the performance loss although it is possible that the presence of impurities in the air may have promoted corrosion of the tubing. 


\section{INTRODUCTION}

This final report covers the work that was conducted in the examination of impurity effects on solid oxide fuel cell performance. The report is divided into three parts. In the first part the effects of the fuel impurities $\mathrm{NH}_{3}, \mathrm{HCl}, \mathrm{H}_{2} \mathrm{~S}$, and $\mathrm{Si}$ are examined. These impurities were chosen because they are the most likely impurities to be found in coal derived fuel gas. Second part of the report discusses the role of copper on the long term stability of the cell anode structure. Copper is found in small quantities in the nickel anode and desulfurizing catalyst used in SOFC generators. Presence of copper in the fuel electrode can also arise from its presence in bonding slurry. And, in the third part of the report the effects of air impurities - water vapor, sulfur dioxide, and sea water mist — are examined. 


\section{COAL DERIVED FUEL GAS IMPURITIES}

\subsection{OBJECTIVES}

One objective of this study is to identify the long-term tolerance of the tubular solid oxide fuel cell (SOFC) to coal-derived fuel gas containing a mixture of three impurities: hydrogen sulfide $\left(\mathrm{H}_{2} \mathrm{~S}\right)$, hydrogen chloride $(\mathrm{HCl})$, and ammonia $\left(\mathrm{NH}_{3}\right)$, with the SOFC operating at $350 \mathrm{~mA} / \mathrm{cm}^{2}$. Another objective is to learn whether the performance of the SOFC at $350 \mathrm{~mA} / \mathrm{cm}^{2}$ would be affected by silica $\left(\mathrm{SiO}_{2}\right)$ in the fuel gas. Post-test analyses were carried out to determine any structure or chemical changes of the SOFC.

\subsection{BACKGROUND}

These tests, which provide a basis for estimating the effects of operating the SOFC in the presence of specific amounts of the coal gas impurities $\mathrm{NH}_{3}, \mathrm{HCl}, \mathrm{H}_{2} \mathrm{~S}$, and $\mathrm{Si}$, significantly relate to the Fossil Energy Program by:

- Providing information and guidance tow ard SOFC materials and designs that adapt best to coal gas impurities.

- Contributing to the development of an efficient and environmentally acceptable SOFC power generation system by establishing coal gas clean-up criteria for system engineering.

\subsection{EXPERIMENTAL}

Full-scale present-technology SOFCs were operated at $1000^{\circ} \mathrm{C}$ and $350 \mathrm{~mA} / \mathrm{cm}^{2}$ to determine performance in fuel gas containing various coal-derived impurities. This report details testing of the effect of three impurities in combination: $\mathrm{NH}_{3}, \mathrm{HCl}$, and $\mathrm{H}_{2} \mathrm{~S}$; and also the effect of the single impurity $\mathrm{Si}$. The fuel gas employed in testing of the three combined impurities and in an initial test evaluating $\mathrm{Si}$ as a fuel impurity represents the product obtainable from a Texaco 
Entrained-Bed oxygen-blown coal gasifier at $776^{\circ} \mathrm{C}$ after external distribution.

Table 2.1 gives the fuel gas composition.

Table 2.1- Simulated O2-Blown Coal Gas

\begin{tabular}{|c|c|}
\hline Gas & Mole, $\%$ \\
\hline $\mathrm{CO}$ & 37.2 \\
\hline $\mathrm{H}_{2}$ & 34.1 \\
\hline $\mathrm{CH}_{4}$ & 0.3 \\
\hline $\mathrm{CO}_{2}$ & 14.4 \\
\hline $\mathrm{H}_{2} \mathrm{O}$ & 13.2 \\
\hline $\mathrm{N}_{2}$ & 0.8 \\
\hline
\end{tabular}

In other increasingly severe tests involving the single impurity, $\mathrm{Si}$, the carryover of Si is enhanced by employing simulated partially reformed natural gas with progressively higher initial $\mathrm{H}_{2} \mathrm{O}$ concentrations as shown in Table 2.2.

Table 2.2 - Simulated Partially Reformed Natural Gas

\begin{tabular}{|l|c|c|}
\hline & \multicolumn{2}{|c|}{ Mole \% } \\
\hline Gas & Comp. A & Comp. B \\
\hline $\mathrm{CO}$ & 15.7 & 28.4 \\
\hline $\mathrm{H}_{2}$ & 36.2 & -- \\
\hline $\mathrm{CH}_{4}$ & 3.3 & 11.6 \\
\hline $\mathrm{CO}_{2}$ & 18.6 & 2.9 \\
\hline $\mathrm{H}_{2} \mathrm{O}$ & 26.2 & 56.7 \\
\hline
\end{tabular}

Upon completion of testing, cells were examined in detail for evidence of physical or chemical damage. Experimental specifics of electrical testing and the theoretical basis of data interpretation are given in the Proceedings of the Third Annual Fuel Cells Contractors Meeting, pp. 109, 110. 


\subsection{RESULTS AND DISCUSSION}

\subsubsection{Extended SOFC Testing at $1000^{\circ} \mathrm{C}$ with $\mathrm{NH}_{3}, \mathrm{HCl}$, and $\mathrm{H}_{2} \mathrm{~S}$ Impurities}

Two full scale (50-cm length) SOFCs, representative of $25 \mathrm{~kW}$ generator cells in the field, were electrically connected in series and operated at $1000^{\circ} \mathrm{C}$ and 350 $\mathrm{mA} / \mathrm{cm}^{2}$. An initial run of approximately 150 hours served to establish base-line performance in $89 \% \mathrm{H}_{2}, 11 \% \mathrm{H}_{2} \mathrm{O}$ fuel at $85 \%$ fuel utilization and 4 stoichs, air (Figure 2.1). Then, for approximately 200 hours, a similar base-line was established for operation in simulated coal gas fuel (Table 2.1). Finally, the fuel impurity components were sequentially added, as indicated in Figure 2.1. The cumulative effect on performance is shown in Table 2.3.

These data reveal no strong association of cell resistance with cell performance change in the cases of $\mathrm{NH}_{3}$ and $\mathrm{HCl}$. When $\mathrm{H}_{2} \mathrm{~S}$ is added, resistance increases account for a minor part of the $0.06 \mathrm{~V}$ decline observed for each cell over the first 24 hours. Cell resistances thereafter change linearly, along with linearly declining voltages. In this latter phase, resistance accounts for a major part of each observed cell voltage decline. Resistances noted here are total resistance increases; they do not differentiate between impurity-related resistances and the base-line resistance increase for the cells running without impurities.

\subsubsection{SOFC Testing at $1025^{\circ} \mathrm{C}$ with $\mathrm{NH}_{3}, \mathrm{HCl}$, and $\mathrm{H}_{2} \mathrm{~S}$ Impurities}

The same two SOFCs were subsequently continued in operation, but at a moderately higher temperature, $1025^{\circ} \mathrm{C}$. As Figure 2.2 demonstrates, \#1 cell tended to decline more slowly and \#2 cell continued to decline at the same rate as when they were operating at $1000^{\circ} \mathrm{C}$. Later operation, without impurities, at $1025^{\circ} \mathrm{C}$ for 450 hours served to improve performance and stabilize the cells. When operation at $1000^{\circ} \mathrm{C}$ resumed, the cell resistance trend lines returned to approximately the original $\mathrm{R}$ versus $\mathrm{t}$ slopes observed during 0-500 hours on test, signifying cessation of impurity-related voltage degradation. 


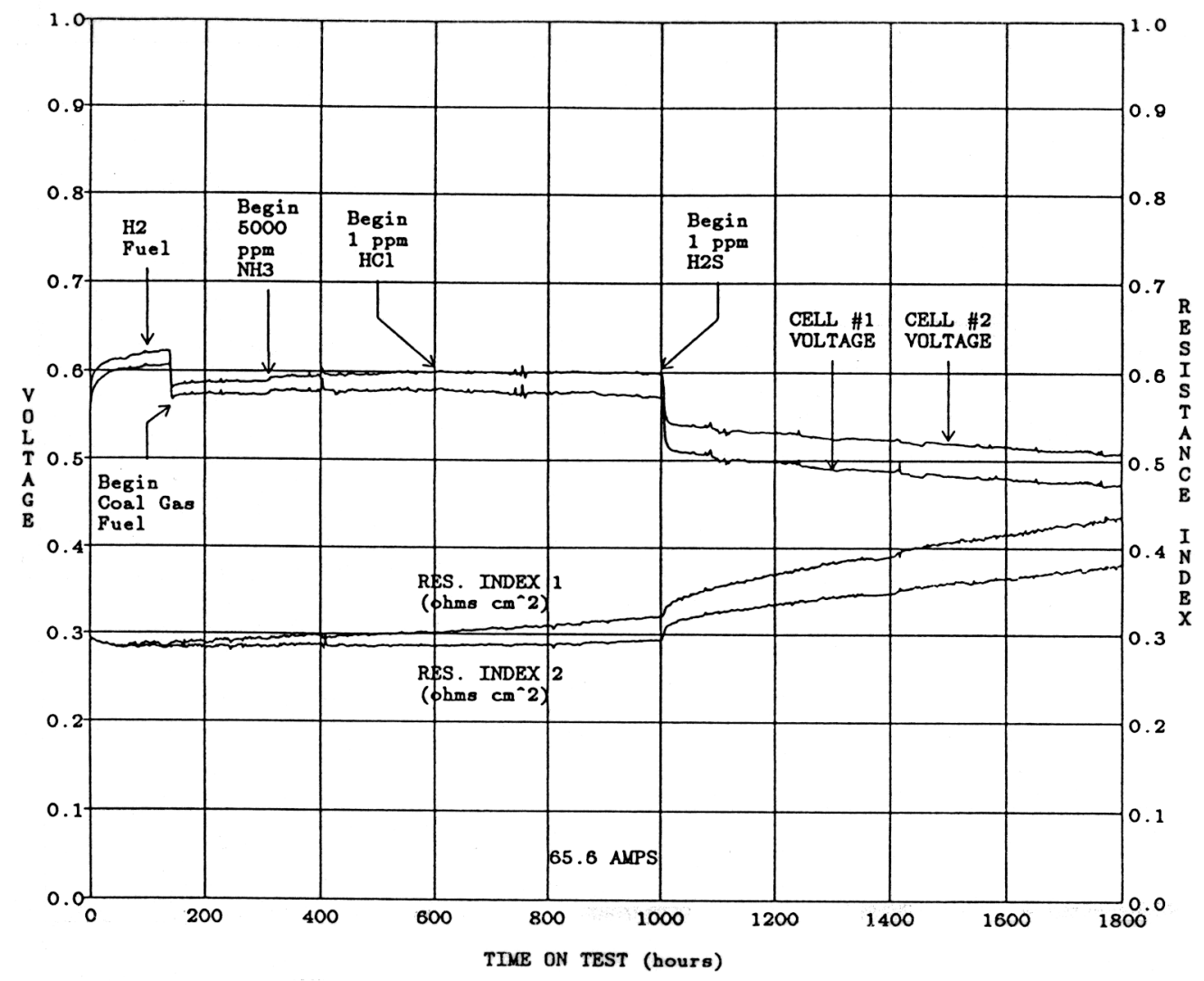

Figure 2.1 - SOFC performance at $1000^{\circ} \mathrm{C}$ and $350 \mathrm{~mA} / \mathrm{cm}^{2}, 85 \%$ fuel utilization and $25 \%$ air utilization. Fuel $=$ simulated air-blown coal gas Table 1). 
Table 2.3 - Effect of Three Impurities on SOFC Operation at $1000^{\circ} \mathrm{C}$ and $350 \mathrm{~mA} / \mathrm{cm}^{2}$ (From Figure 2.1 ).

\begin{tabular}{|c|c|c|c|c|c|c|c|c|}
\hline & & & \multicolumn{3}{|c|}{$\begin{array}{c}\text { Initial (24 Hours) } \\
\text { Voltage Drop (V) }\end{array}$} & \multicolumn{2}{c|}{$\begin{array}{c}\text { Long-Term } \\
\text { V versus t } \\
\text { Trend Line } \\
(\Delta V / 1000 \text { hrs })\end{array}$} & \multicolumn{2}{c|}{$\begin{array}{c}\Delta \text { V Due to Cell } \\
\text { Resistance Index } \\
\text { Change }(\Delta V / 1000 \text { hrs })\end{array}$} \\
\hline $\begin{array}{c}\text { Impurity } \\
\text { Species }\end{array}$ & $\begin{array}{c}\text { Order of } \\
\text { Addition }\end{array}$ & $\mathrm{ppm}$ & Cell \#1 & Cell \#2 & Cell \#1 & Cell \#2 & Cell \#1 & Cell \#2 \\
\hline None & -- & -- & -- & -- & +0.01 & +0.01 & -0.01 & -0.003 \\
\hline $\mathrm{NH}_{3}$ & 1 & 5000 & 0 & 0 & +0.01 & +0.01 & -0.01 & -0.003 \\
\hline $\mathrm{HCl}$ & 2 & 1 & 0 & 0 & -0.01 & 0.00 & -0.01 & -0.003 \\
\hline $\mathrm{H}_{2} \mathrm{~S}$ & 3 & 1 & .06 & .06 & -0.01 & -0.04 & -0.04 & -0.025 \\
\hline
\end{tabular}




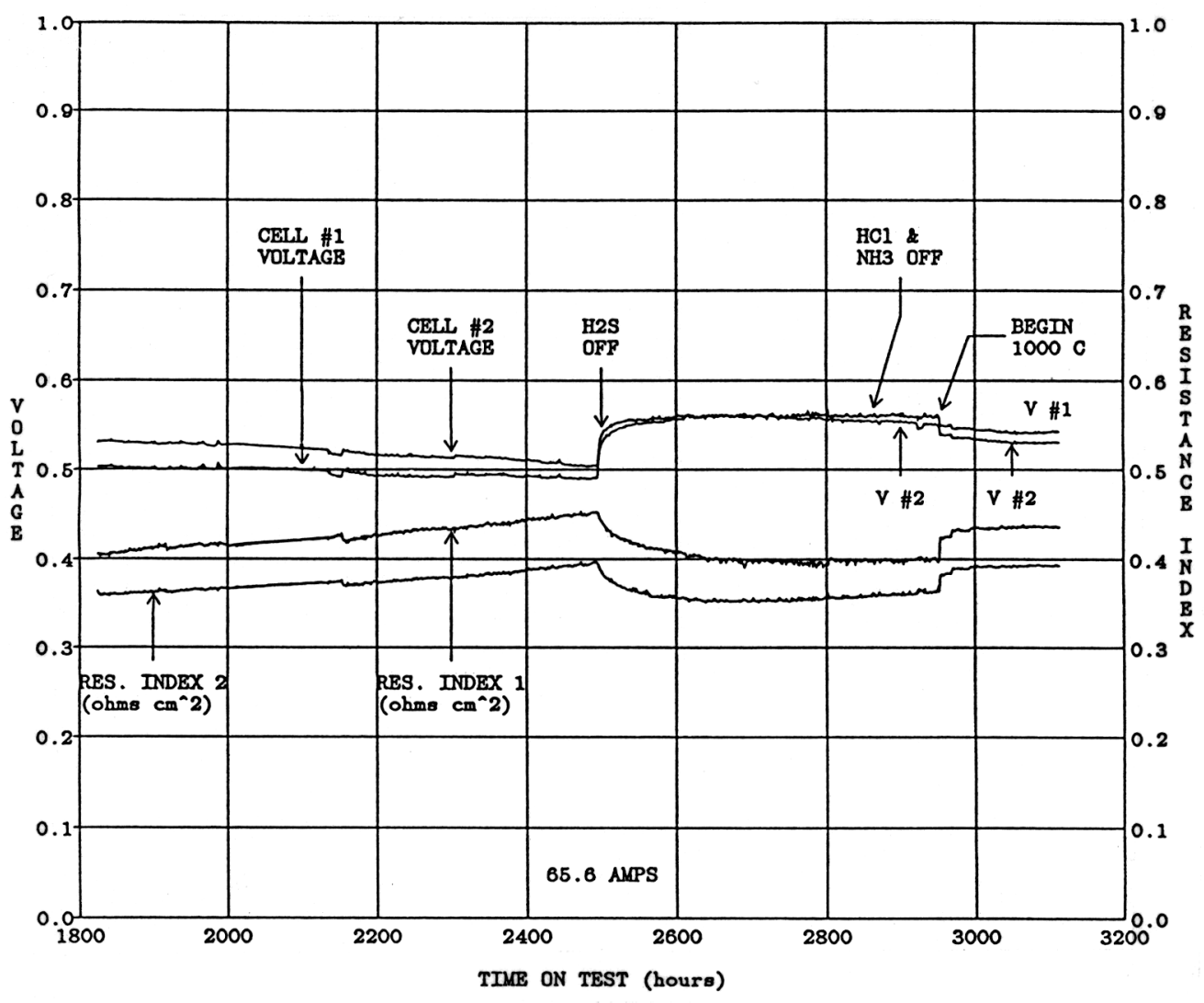

Figure 2.2 - SOFC performance at $1025^{\circ} \mathrm{C}$ and $350 \mathrm{~mA} / \mathrm{cm} 2,85 \%$ fuel utilization and $25 \%$ air utilization. Fuel $=$ simulated air-blown coal gas containing $5000 \mathrm{ppm} \mathrm{NH3,} 1 \mathrm{ppm} \mathrm{HCl}$ and 1 ppm $\mathrm{H}_{2} \mathrm{~S}$. 


\subsubsection{Follow-On Long Term SOFC Testing at $1000^{\circ} \mathrm{C}$}

A new two-cell test was initiated employing $\mathrm{NH}_{3}$ at $5000 \mathrm{ppm}, \mathrm{HCl}$ at $1 \mathrm{ppm}$, but with $\mathrm{H}_{2} \mathrm{~S}$ reduced to $0.1 \mathrm{ppm}$. After approximately 500 hours, this test showed no measurable voltage degradation and no change in the resistance versus time trend line (Figure 2.3). Extension of testing at this level of impurities to approximately 3000-4000 hours is expected to show continued stable performance levels.

\subsubsection{Overall Performance Loss in the Presence of $\mathrm{NH}_{3}, \mathrm{HCl}$ and $\mathrm{H}_{2} \mathrm{~S}$}

- Generally, changes in the slope of resistance index versus time can be attributed to the effect of fuel gas impurities. In the absence of impurities, resistance index measurements show a relatively constant slope versus time and therefore can be taken as a reference slope. Changes in the slope of resistance versus time above the reference slope tend to relate closely to impurity-related voltage losses.

- $\mathrm{H}_{2} \mathrm{~S}$ is responsible for most voltage losses experienced by this particular cell design when operated at 5000 ppm $\mathrm{NH}_{3}, 1 \mathrm{ppm} \mathrm{HCl}$ and 1 ppm $\mathrm{H}_{2} \mathrm{~S}$.

- In the presence of $\mathrm{H}_{2} \mathrm{~S}$, cell resistances increase at a lower rate at $1025^{\circ} \mathrm{C}$, than at $1000^{\circ} \mathrm{C}$. This is interpreted as primarily an $\mathrm{H}_{2} \mathrm{~S}$ desorption effect which exposes more nickel surface area as temperature increases.

- When $\mathrm{H}_{2} \mathrm{~S}$ is removed entirely, cell resistances return to the lower rates of increase shown at the beginning of cell operation, but with an offset reflecting permanent performance loss.

- Irreversible voltage losses, primarily due to $1 \mathrm{ppm} \mathrm{H}_{2} \mathrm{~S}$, were observed to be approximately $1 \% / 1000$ hours over the first 2000 hours at $1000^{\circ} \mathrm{C}$ and $350 \mathrm{~mA} / \mathrm{cm}^{2}$.

- No irreversible voltage losses were observed for SOFCs running over 500 hours at $1000^{\circ} \mathrm{C} ; 350 \mathrm{~mA} / \mathrm{cm}^{2}$ on fuel containing $0.1 \mathrm{ppm} \mathrm{H}_{2} \mathrm{~S}$. 


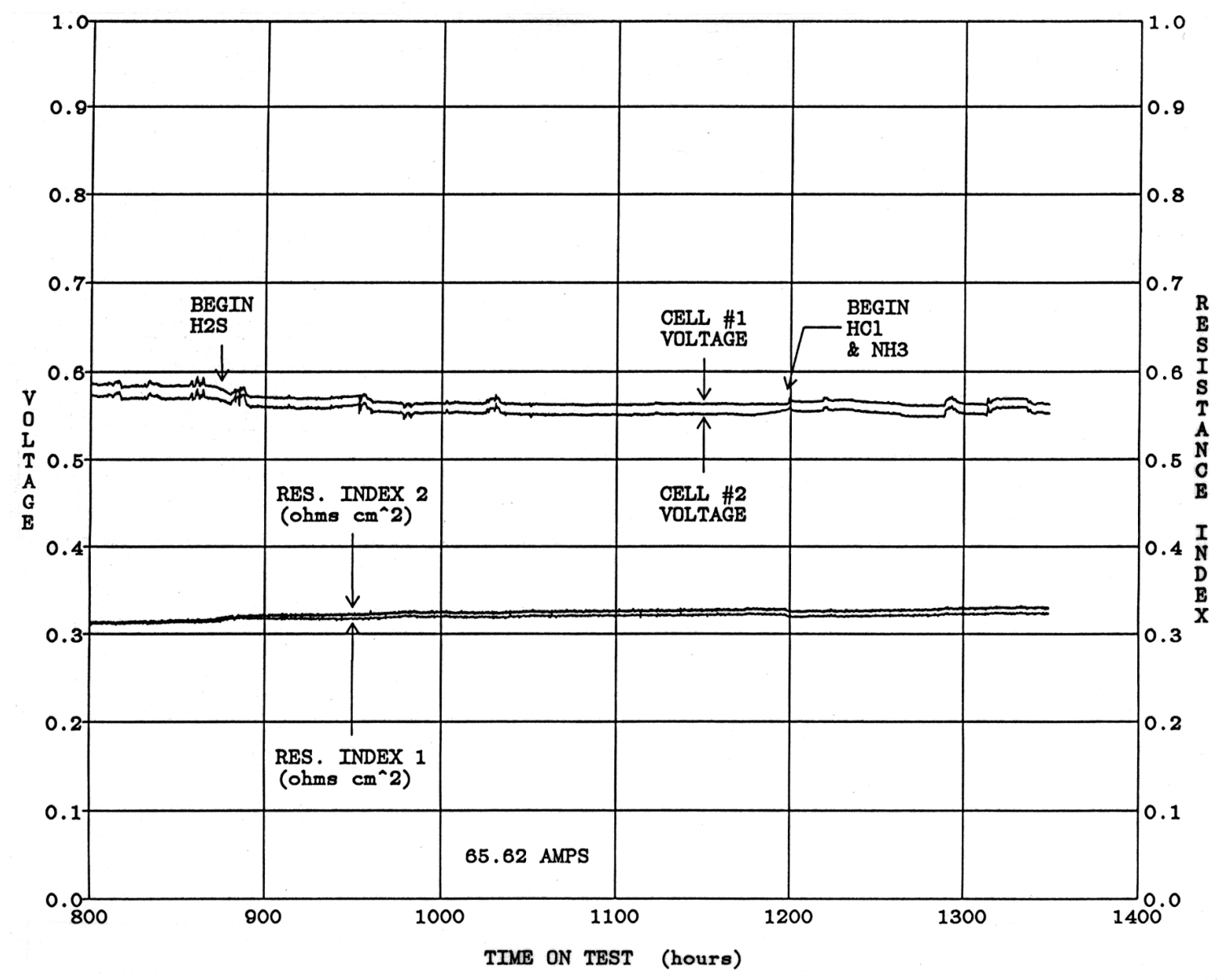

Figure 2.3 - SOFC performance at $1000^{\circ} \mathrm{C}$ and $350 \mathrm{~mA} / \mathrm{cm}^{2}, 85 \%$ fuel utilization and $25 \%$ air utilization. Fuel = simulated air-blown coal gas containing $5000 \mathrm{ppm} \mathrm{NH}_{3}, 1 \mathrm{ppm} \mathrm{HCl}$ and $0.1 \mathrm{ppm} \mathrm{H}_{2} \mathrm{~S}$. 


\subsubsection{Initial Test at $1000^{\circ} \mathrm{C}$ and $350 \mathrm{~mA} / \mathrm{cm}^{2}$ Using Coal-Derived Fuel Gas with Silicon Impurity}

Two full-scale $(50 \mathrm{~cm}$ ) length) SOFCs showed near-normal performance after approximately 2400 hours exposure to simulated coal gas contaminated with silicon by permeation through a fixture held at $900-1000^{\circ} \mathrm{C}$. The fixture is "Duraboard", a porous material composed of $74 \% \mathrm{Al}_{2} \mathrm{O}_{3}$ and $26 \% \mathrm{SiO}_{2}$. Some accumulation of silicon on exposed nickel in the fuel electrode (Figure 2.4) was insufficient to cause appreciable degradation. Silicon detected is assumed to be present as silica, $\mathrm{SiO}_{2}$.

\subsubsection{Short-Term SOFC Testing at $1000^{\circ} \mathrm{C}$ and $350 \mathrm{~mA} / \mathrm{cm}^{2}$ Using Simulated Partially Reformed Natural Gas}

A follow-on test employing partially reformed natural gas was conducted in order to investigate the effect of increasing $\mathrm{H}_{2} \mathrm{O}$ levels on silicon transport. This test differed from the initial test with respect to the composition of the fuel. Compared to approximately $13.2 \% \mathrm{H}_{2} \mathrm{O}$ in the simulated coal gas, these experiments employed simulated partially reformed natural gas with higher $\mathrm{H}_{2} \mathrm{O}$ concentrations as described in Table 2.2

The effect of silicon on SOFC operation at $1000^{\circ} \mathrm{C}, 350 \mathrm{~mA} / \mathrm{cm}^{2}, 4$ stoichs, air, and $85 \%$ fuel utilization is shown in Figure 2.5. On $\mathrm{H}_{2}$ fuel, the cells can be seen to improve in performance over approximately 600 hours. When continued with composition "A" fuel $\left(26.2 \% \mathrm{H}_{2} \mathrm{O}\right)$ performance still increased slightly, with a tendency to stabilize. The resistance index of both cells changed from a constant level to a slightly positive slope, consistent with the expected faster delivery of silicon to the test cells.

Upon changing to fuel gas composition "B", with $56.7 \% \mathrm{H}_{2} \mathrm{O}$, the loaded voltage of each cell showed a stable-to-declining characteristic. Concurrently, the cell resistance index lines began a new and higher positive slope equivalent to a voltage degradation of 0.008 to $0.012 \mathrm{~V}$ per 1000 hours. Ultimately, silicon accumulation may fully counterbalance the natural tendency of these cells to improve; then the effect of increasing cell resistance is expected to be seen in a negative slope for loaded voltage versus time. 


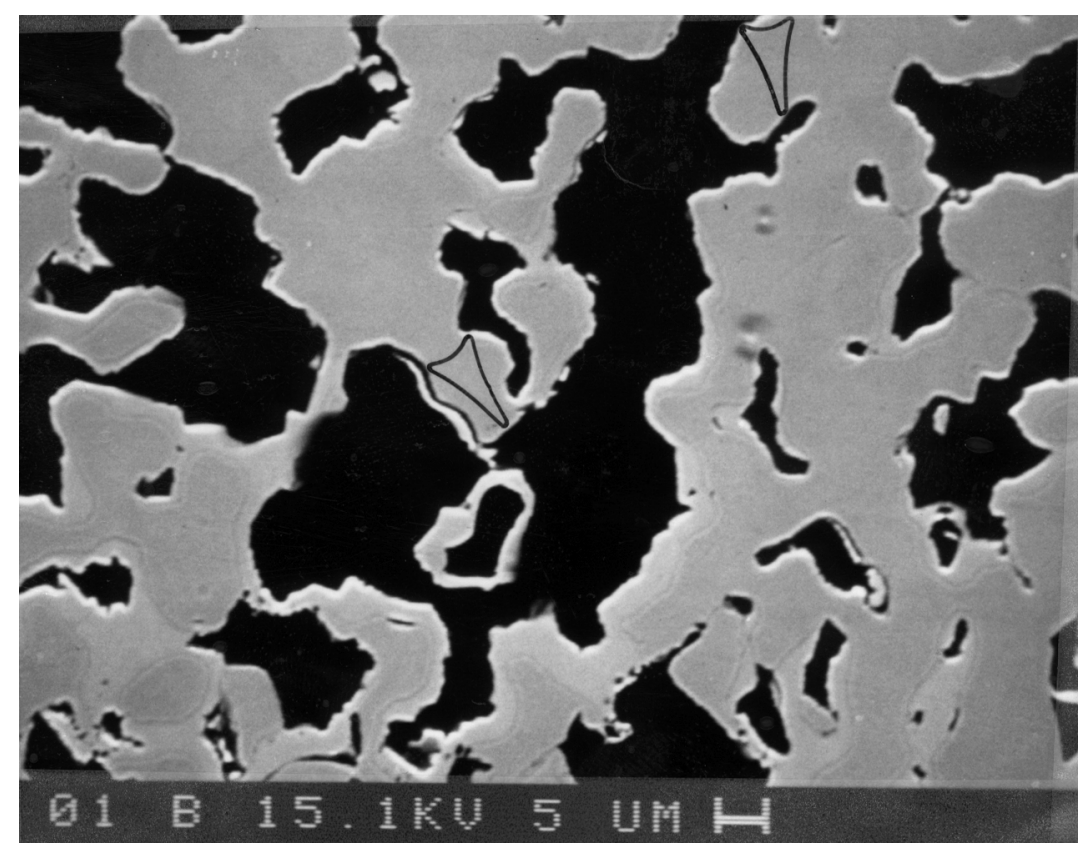

Backscattered electrons -- Arrows indicate silicon-rich areas

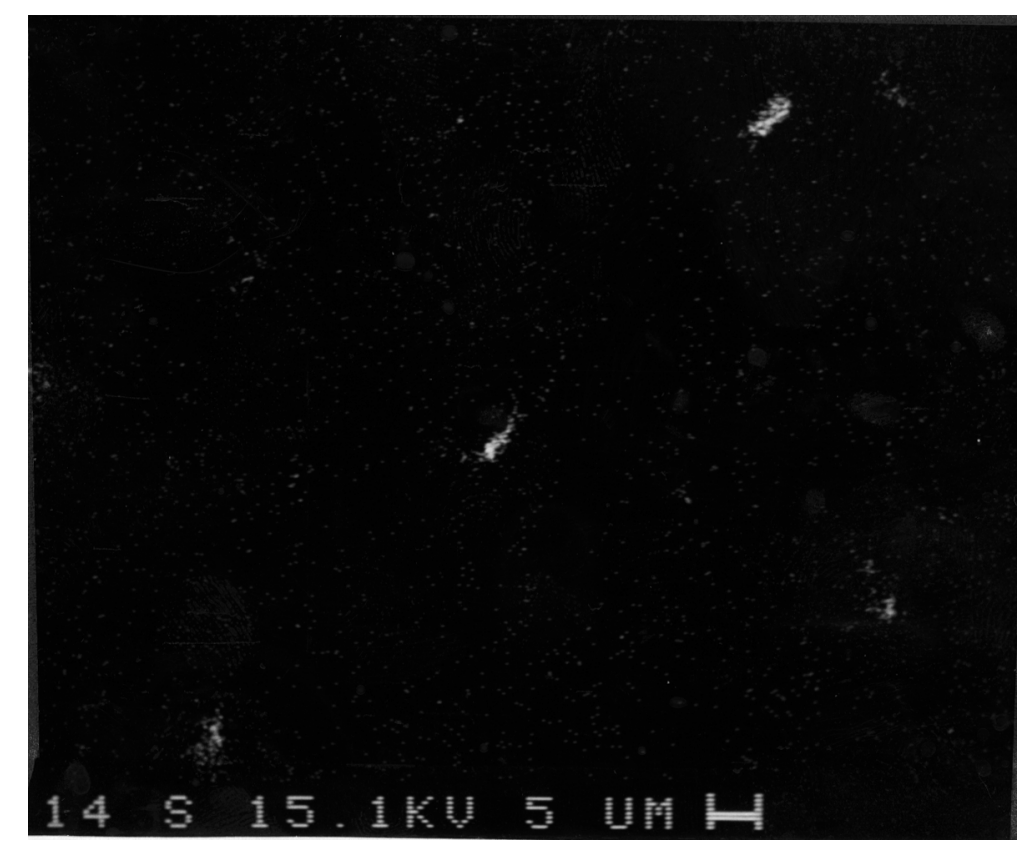

Silicon element map of area shown above

Figure 2.4 - Location of silicon-rich areas at exposed nickel network of SOFC fuel electrode, after approximately 2,400 hours of operation at $1000^{\circ} \mathrm{C}$ in simulated coal gas $\left(13 \% \mathrm{H}_{2} \mathrm{O}\right)$ with $\mathrm{Si}$ impurity. 


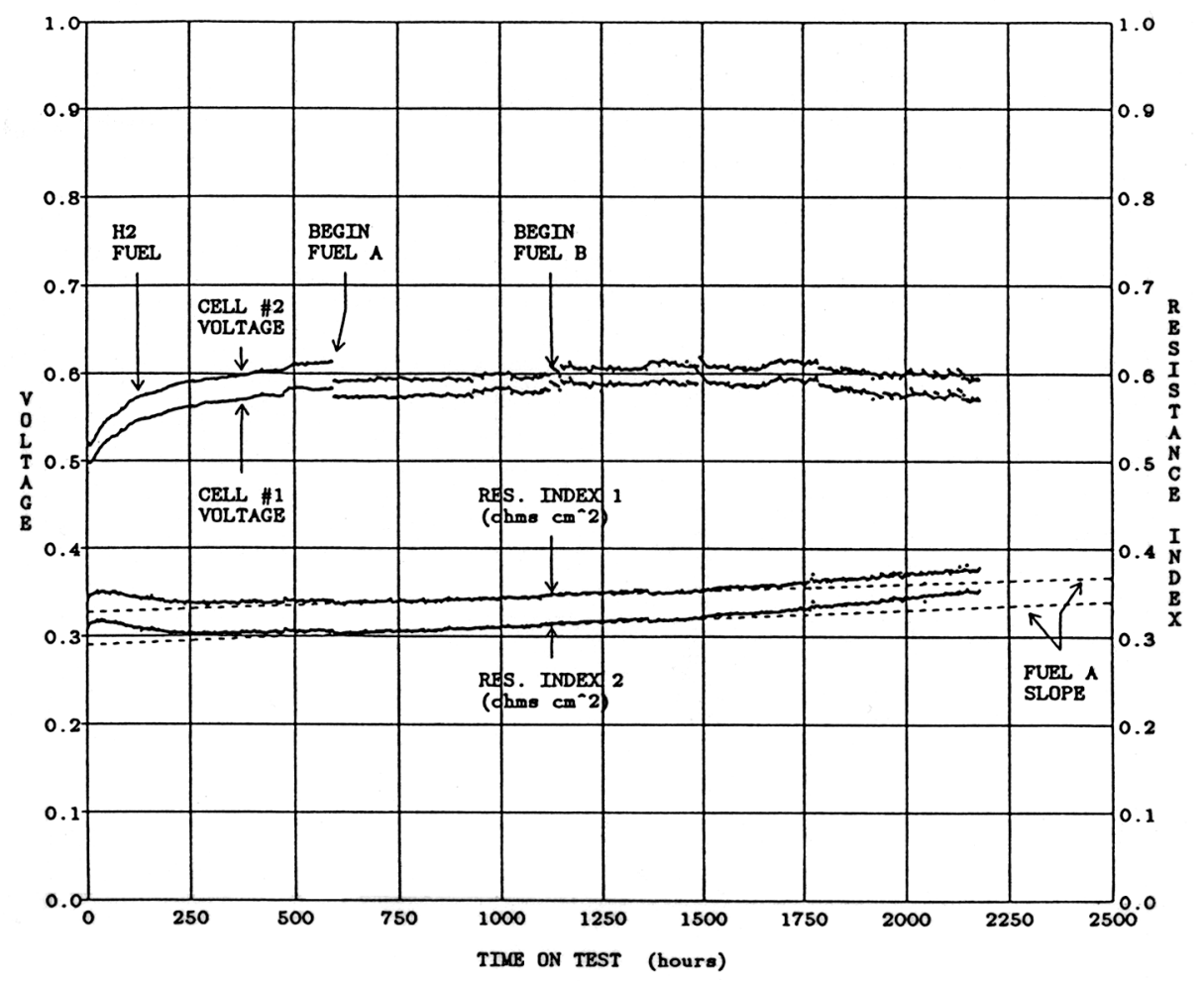

Figure 2.5 - SOFC performance at $1000^{\circ} \mathrm{C}$ and $350 \mathrm{~mA} / \mathrm{cm}^{2}, 85 \%$ fuel utilization and $25 \%$ air utilization. Fuel containing 1) $11 \% \mathrm{H}_{2} \mathrm{O}$, 2) $26.2 \% \mathrm{H}_{2} \mathrm{O}$ (Fuel A), 3) $56.7 \% \mathrm{H}_{2} \mathrm{O}$ (Fuel B) passing over silica, $\mathrm{SiO}_{2}$. 


\subsubsection{Silicon Carryover as a Fuel Contaminant}

Silicon transport may occur when the $\mathrm{H}_{2} \mathrm{O}$ content in the fuel contacts the silica present in the Duraboard fixture through which the fuel must flow:

$$
\mathrm{SiO}_{2}(s)+2 \mathrm{H}_{2} \mathrm{O}(\mathrm{g}) \rightarrow \mathrm{Si}(\mathrm{OH})_{4}(g)
$$

As the $\mathrm{CH}_{4}$ component in the fuel reforms to $\mathrm{CO}$ and $\mathrm{H}_{2}$, water is consumed:

$$
\mathrm{CH}_{4}+n \mathrm{H}_{2} \mathrm{O} \rightarrow \mathrm{CO}+3 \mathrm{H}_{2}+(n-1) \mathrm{H}_{2} \mathrm{O}
$$

which favors reversal of reaction:

$$
\mathrm{Si}(\mathrm{OH})_{4}(g) \rightarrow \mathrm{SiO}_{2}(s)+2 \mathrm{H}_{2} \mathrm{O}(g)
$$

causing silica, $\mathrm{SiO}_{2}(\mathrm{~s})$ to deposit downstream; particularly on the nickel in the fuel electrode (Error! Reference source not found.).

Coverage of nickel by silica should not impede transport of $\mathrm{H}_{2}$ in the fuel electrode. However, it may restrict the outward flow of $\mathrm{H}_{2} \mathrm{O}$. If this is the case, an increase in fuel electrode polarization would be expected and in some cases oxidation of nickel. 


\subsection{CONCLUSIONS}

The major accomplishments of this work can be summarized:

1) A good estimate of impurity-related voltage degradation is obtained by examination of resistance index versus time trend lines and of offsets in these trends due to impurity exposure.

2) Ammonia impurity up to $5000 \mathrm{ppm}$ in simulated coal gas does not present a measurable contribution to SOFC voltage degradation over approximately 2500 hours of testing. As testing time increases, $\mathrm{NH}_{3}$ contaminant effects are expected to be nil.

3) $\mathrm{HCl}$ impurity at $1 \mathrm{ppm}$ in simulated coal gas does not have a detectable effect on SOFC performance up to 2,200 hours under the stated test conditions.

4) $\mathrm{H}_{2} \mathrm{~S}$ impurity at $0.1 \mathrm{ppm}$ in simulated coal gas fuel can be tolerated by state-ofthe-art SOFCs, along with 5000 ppm $\mathrm{NH}_{3}$ and 1 ppm $\mathrm{HCl}$ with no measurable voltage degradation over at least 500 hours.

5) Silicon impurity in coal gas or in insulation can be carried over to the SOFC and deposited. The carryover is enhanced by high $\mathrm{H}_{2} \mathrm{O}$ content $(\sim 50 \%)$ in the fuel.

6) Under conditions expected for oxygen-blown coal gas fuel $\left(\mathrm{H}_{2} \mathrm{O}=13 \%\right)$ silicon is not expected to have a major effect on SOFC performance. 


\section{ADDITIONAL CELL COMPONENT IMPURITIES}

\subsection{OBJECTIVES}

Chemical stability of copper as a bonding/sintering material for attaching nickel felts to cell fuel electrode and interconnection has been evaluated under normal solid oxide fuel cell (SOFC) operating conditions at $1000^{\circ} \mathrm{C}$. Although high temperature sintering experiments conducted in the reducing gas environment indicate the development and formation of excellent cell to nickel felt bonding, long term cell electrical tests conducted at $1000^{\circ} \mathrm{C}$ showed significant interdiffusion of copper into nickel present in the cell fuel electrode and interconnection surface plating. Migration of copper from the bonding layer was also observed and found to be responsible for the densification of the cell fuel electrode and break down of the cell fuel electrode zirconia skeleton.

\subsection{BACKGROUND}

Since SOFC generators operate at a nominal temperature of $1000^{\circ} \mathrm{C}$ and cell temperatures vary from 800 to $1020^{\circ} \mathrm{C}$ along the cell length depending on its location within the generator, it was found necessary to develop sintering materials and processes by which cells can be sintered within the generator at lower temperatures without any external load applied to the cell assembly. Literature review conducted on the candidate thermochemically stable materials indicated that there remains a possibility of using only copper, silver, cobalt and other noble metals in the fuel gas environment of the fuel cell because of their resistance to oxidation. Above materials will also remain electronically conducting and chemically stable in the metallic form at the oxygen partial pressures representative of the fuel gas of the SOFC. Other criteria for the selection of the candidate bonding material for joining the cell and felt included the cost 
effectiveness of the material and the demon-stration of adequate long term physical stability and bond strength under the normal cell operating conditions. Noble metals such as gold and platinum were not considered for further evaluation because of unfavorable economics. Use of cobalt for joining cell components was also considered unfavorable because of the higher cost and higher sintering temperature required for bonding cell components and nickel felts. Out of the remaining copper and silver based materials, only copper appeared favorable for application in the cells operating at $1000^{\circ} \mathrm{C}$ because of the higher melting point of copper $\left(1080^{\circ} \mathrm{C}\right)$. Melting point of silver $\left(980^{\circ} \mathrm{C}\right)$ is lower than the cell operating temperature indicating the melting and undesirable migration of the material under normal cell operation.

Chemical and physical properties of copper were reviewed in detail to understand the compatibility of copper with adjacent nickel present in the cell fuel electrode and nickel felts. Chemical stability of metal / metal oxide were calculated from free energy data (1). Table 3.1 summarizes important physical and chemical properties of interest.

Table 3.1 - Physical and Chemical Properties of Nickel and Copper

\begin{tabular}{|l|c|c|}
\hline \multicolumn{1}{|c|}{ Attributes } & Nickel & Copper \\
\hline Melting Point, $\left({ }^{\circ} \mathrm{C}\right)$ & 1455 & 1083 \\
\hline Boiling Point, $\left({ }^{\circ} \mathrm{C}\right)$ & & 2336 \\
\hline & 2900 & \\
\hline Eqlbm. $\log \mathrm{PO}_{2}(\mathrm{M} / \mathrm{MO}) @ 1000^{\circ} \mathrm{C},(\mathrm{atm})$ & $\mathrm{Ni} / \mathrm{NiO}=-9.78$ & $\mathrm{Cu} / \mathrm{Cu} 2 \mathrm{O}=-6.33$ \\
\hline & & \\
\hline Crystal structure & cubic & cubic \\
\hline & & \\
\hline Density, (g/cc) & 8.9 & 8.92 \\
\hline
\end{tabular}

Binary copper - nickel phase diagram (Figure 3.1) indicated the formation of a continuous solid solution (2). Thermal expansion characteristics of copper nickel and their alloys (3) were examined in the temperature range of interest and found to be compatible with nickel. Diffusion couple study between copper in nickel (4) indicated faster diffusion of copper in nickel resulting in the porosity formation 

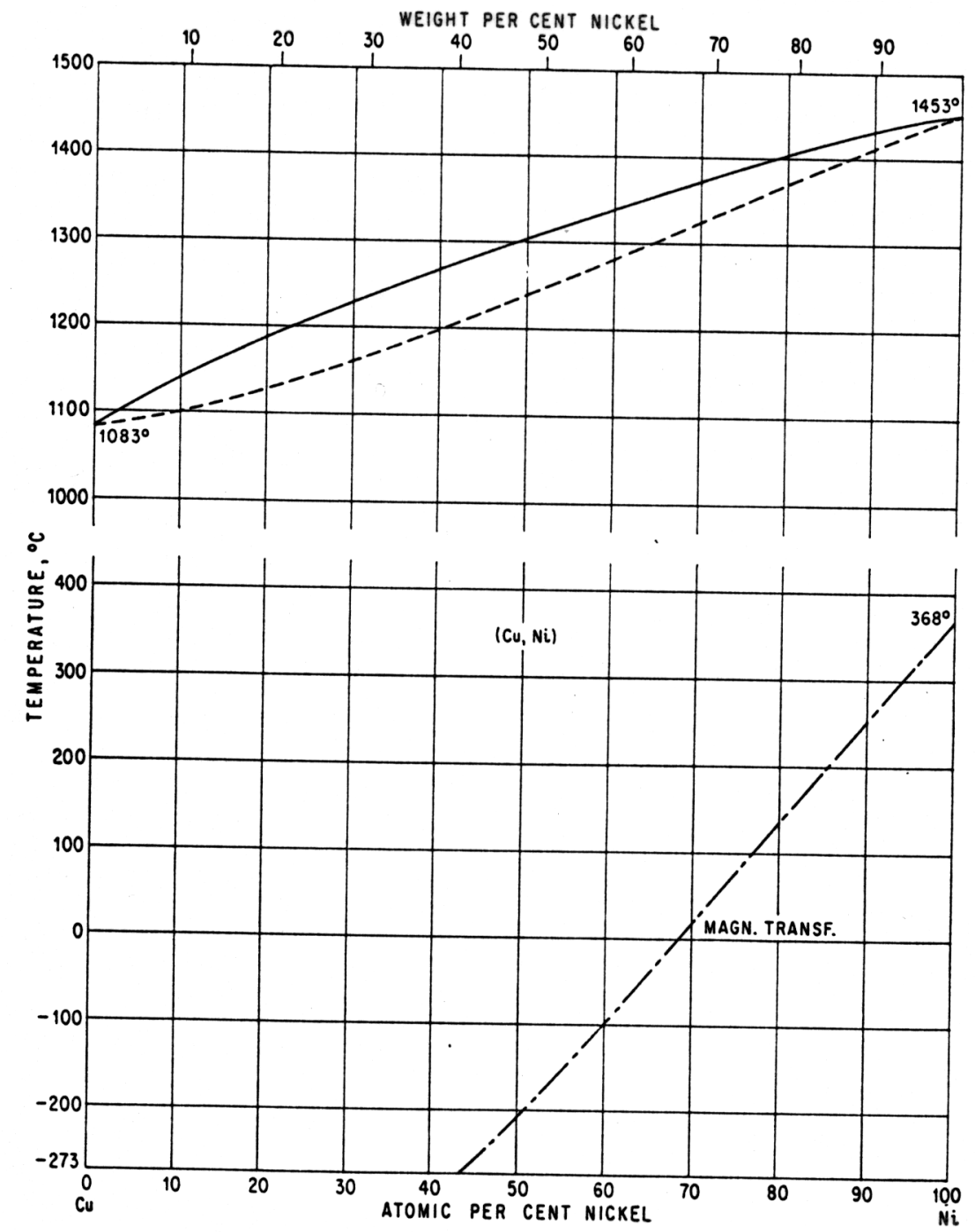

Fig. 347. Cu-Ni

Figure 3.1 - Cu-Ni binary alloy phase diagram (1). A continuous solid solution formation is indicated. 
"Kirkendall void" in copper and net accumulation of material in nickel resulting in the swelling near the diffusion couple interface (Error! Reference source not found.). At elevated temperatures representative of the operating temperature of SOFC, copper rapidly diffuses in nickel forming a copper - nickel alloy. With time, homogenization of the alloy takes place eliminating the initial concentration gradient formed at the interface.

\subsection{EXPERIMENTAL}

Sintered cell - felt assemblies were fabricated using a copper - epoxy slurry. High purity copper powder (Figure 3.3) was used during the experiment. Cells were subsequently installed in a standard cell electrical test fixture for the evaluation of their electrical performance. Standard fixture components and attachment procedures were used. Cell tests were conducted at $1000^{\circ} \mathrm{C}$ in $\mathrm{H}_{2}-11 \% \mathrm{H}_{2} \mathrm{O}$ fuel gas. During electrical test, cells were operated at $85 \%$ fuel and $16 \%$ oxidant utilization. Cell voltage and resistance were monitored during the test. After completion of the electrical test, cells were removed form the test fixtures and visually inspected. Approximately $1 \mathrm{~cm}$ long cell sections from near the cell closed end, mid length and open end were then cut and polished for microstructural evaluation.

\subsection{RESULTS AND DISCUSSION}

Figure 3.4 and Figure 3.5 show the electrical performance data for two cell tests 577 and 578 conducted using the copper slurry. Cell test 577 shows stable cell voltage and resistance during the test whereas cell test 578 shows declining voltage and increase in cell resistance with time. After the termination of the electrical test, cell from test 577 showed uniform bonding with the nickel felt along the cell length whereas cell from test 578 showed separation of the nickel felt over the interconnection (Figure 3.6). When pulled, nickel felts present on both cells showed weak adhesion with the cell fuel electrode and interconnection. 


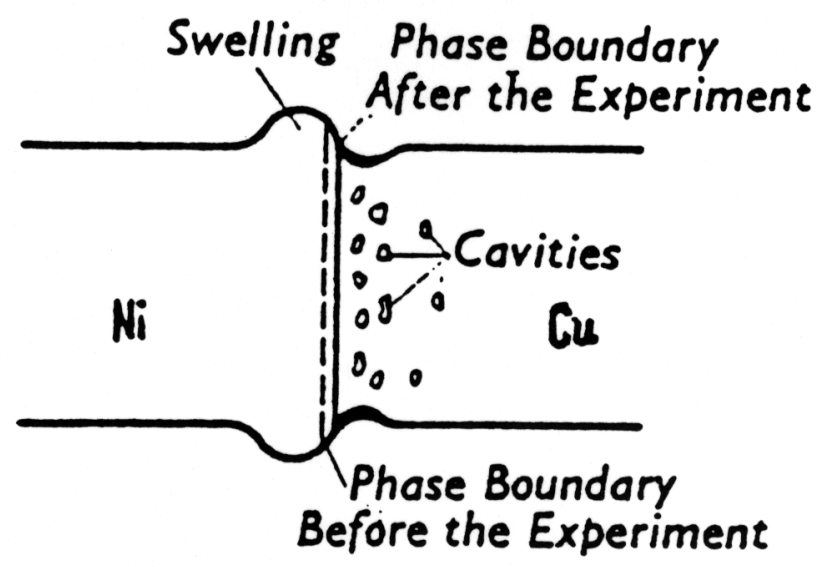

Figure 3.2 - Schematic representation of the Kirkendall effect with "cavity and swelling formation" appearing in the neighborhood of the phase boundary in the nickel-copper system, according to Seith and Kottmann. 

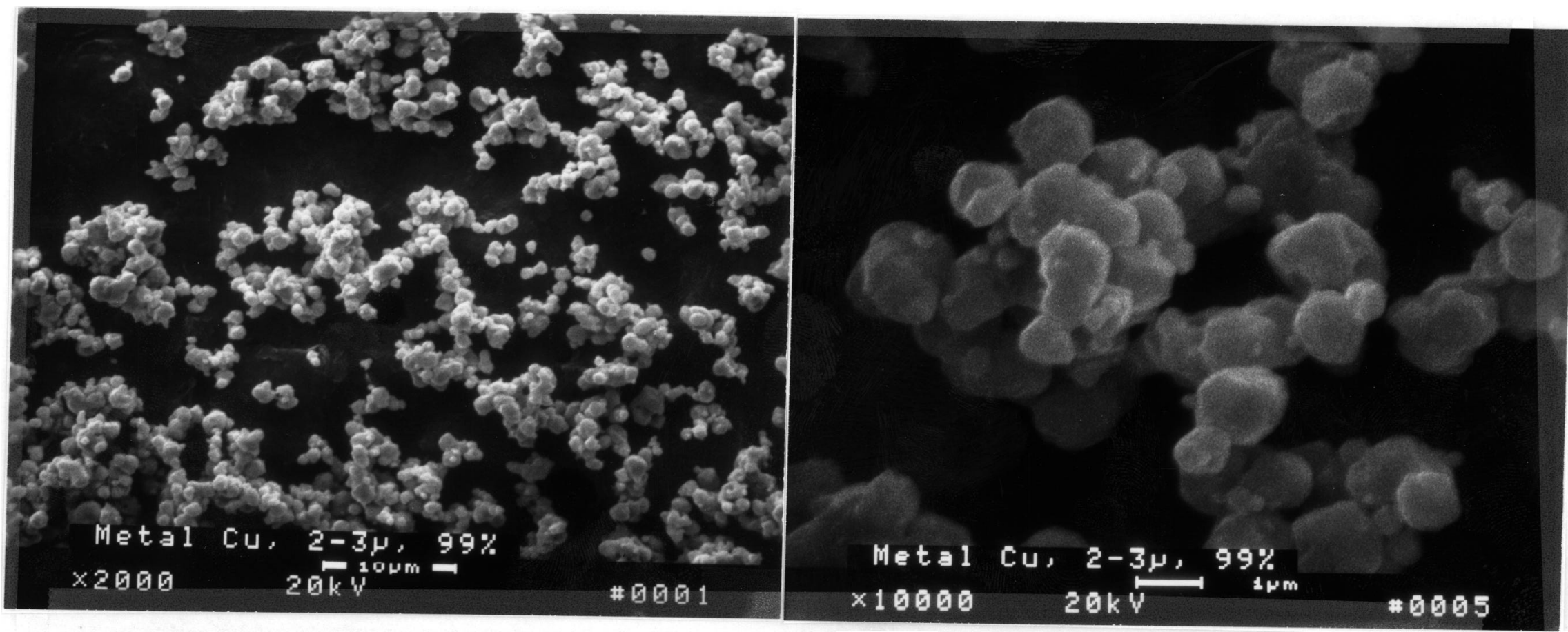

Figure 3.3 - Morphology of copper powder used for bonding experiments. EDS analysis of the powder shows the presence of copper only.

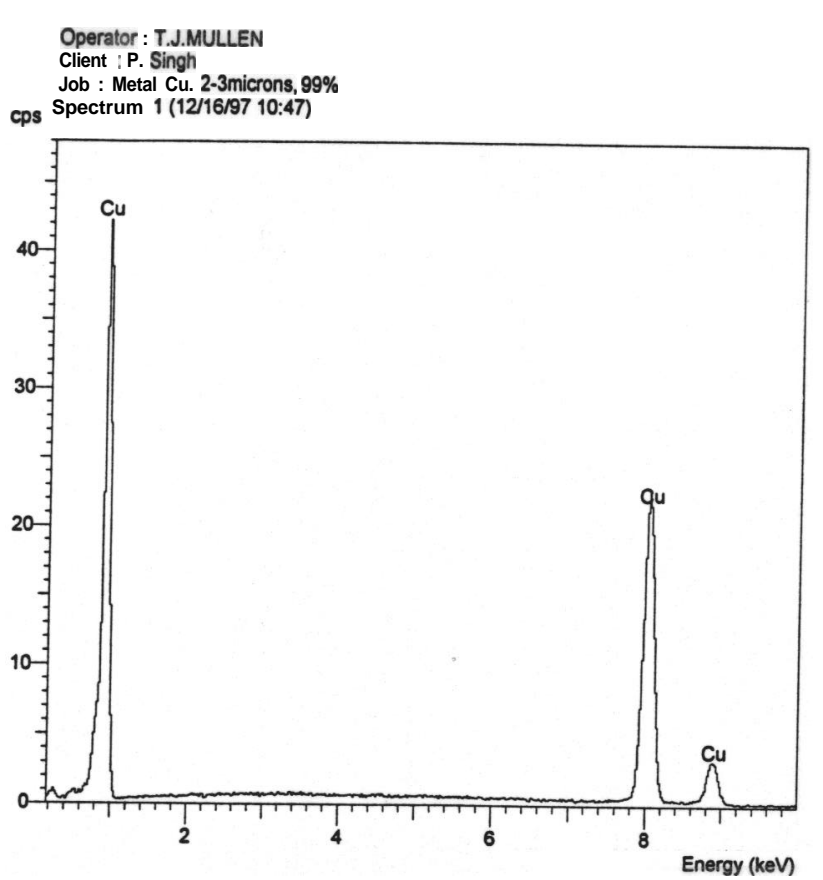




\section{TEST 577}

Objectives: To measure the performance and lifetime of a $15.5 \mathrm{~mm}$ cell which has copper slurry on the IC and a $\mathrm{Ni}$ impregnated $\mathrm{AE}$.

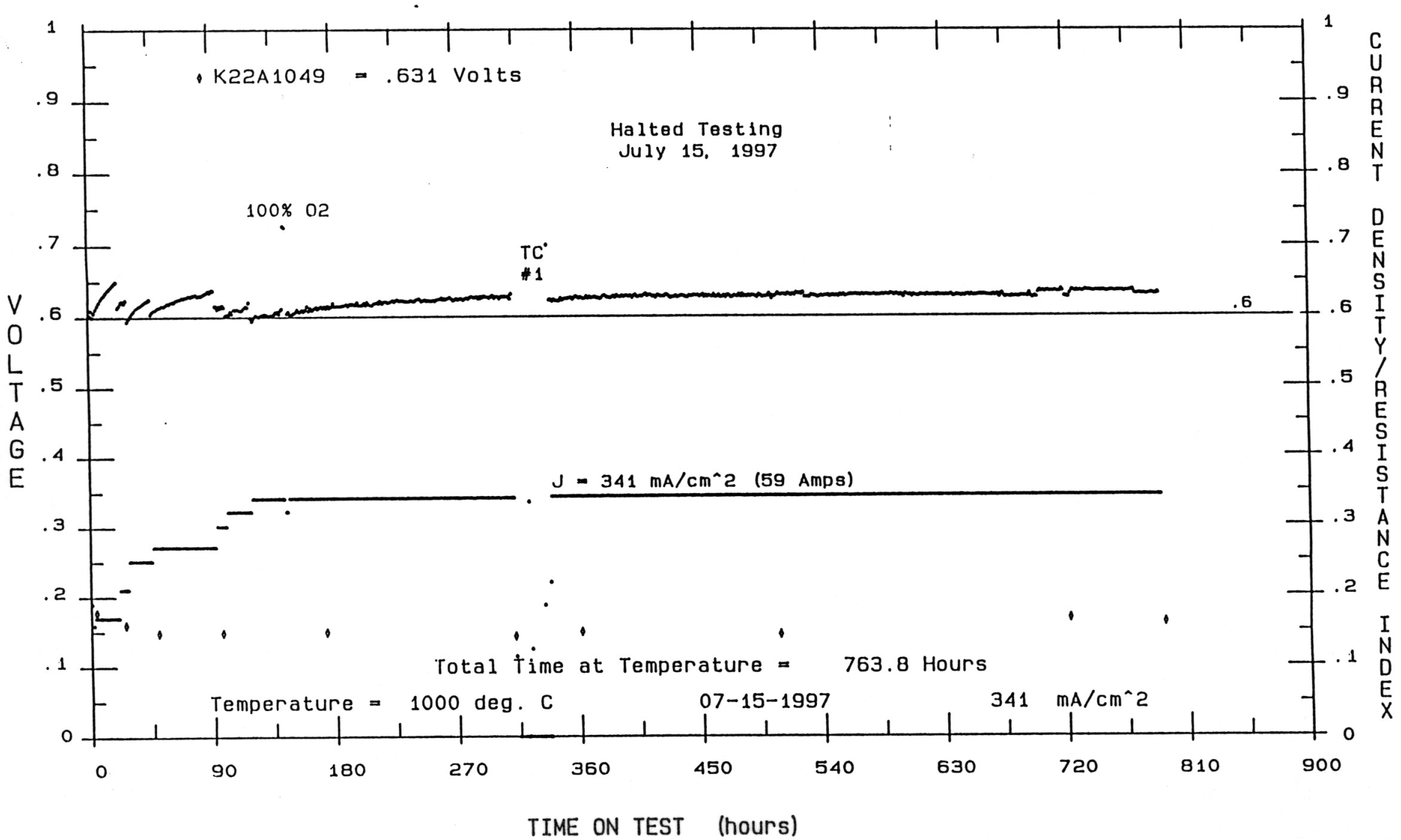

Figure 3.4 - Electrical performance of cell \#577. Cell shows stable voltage and resistance. 


\section{TEST 578}

Objectives: To evaluate an experimental Cu slurry used to bond felts directly to both the IC and the FE. Cu slurry used in place of $\mathrm{Ni} p l a t i n g$.

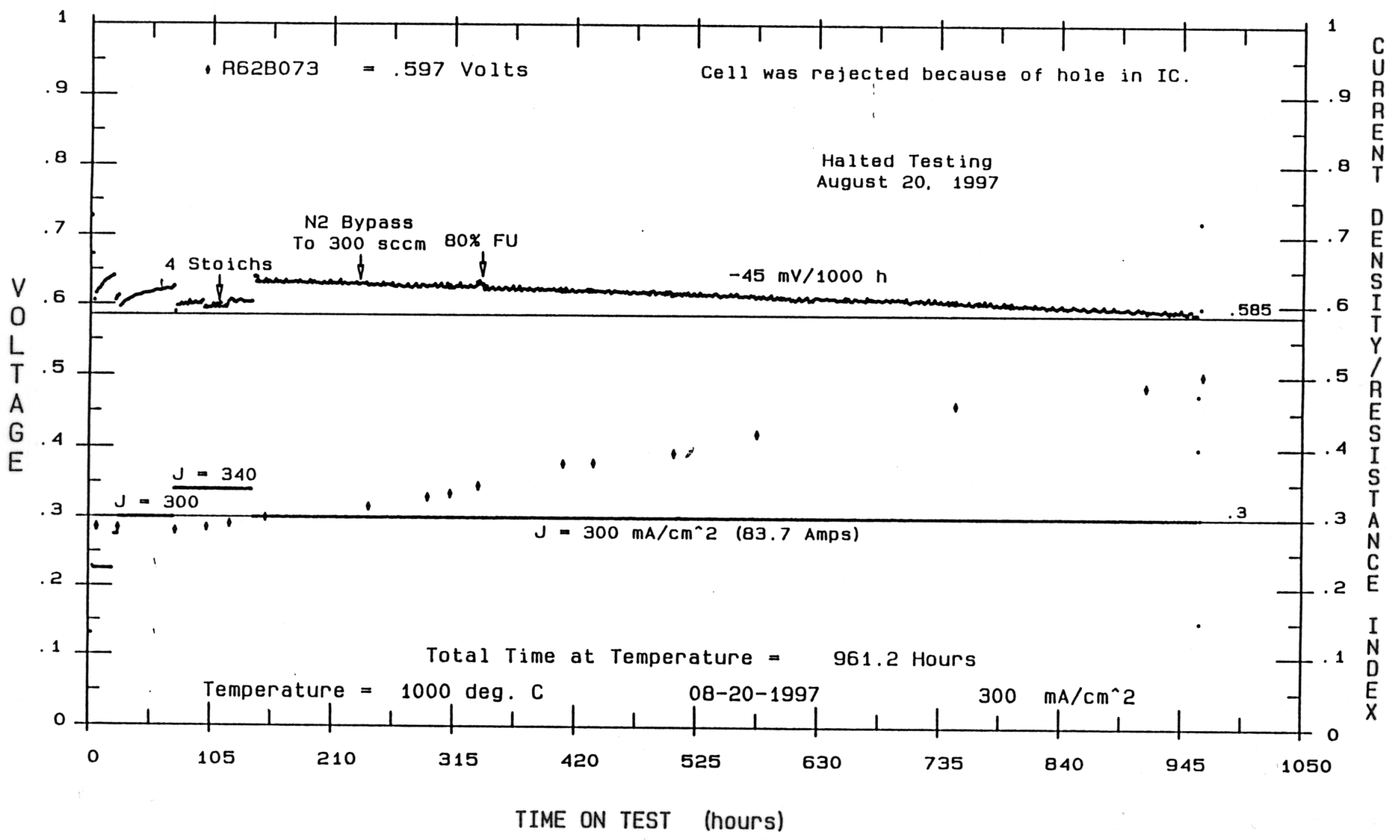

Figure 3.5 - Electrical performance of cell \#578. Cell shows declining voltage and increase in resistance. 


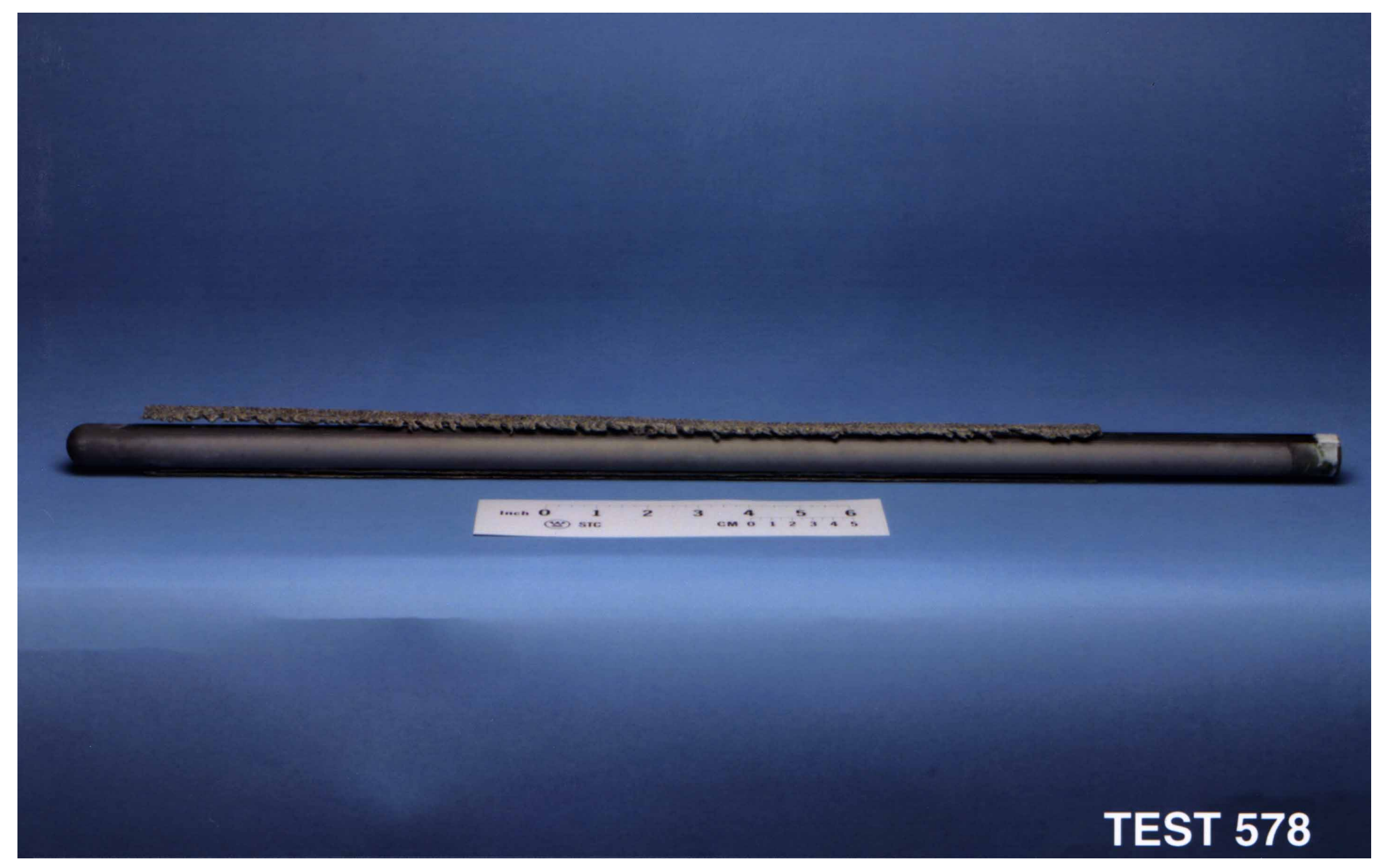

Figure 3.6 - Cell from cell test \#578. Separation of cell and felt near the closed end is observed. 
Polished cross sections of cell - felt assemblies were examined by optical and scanning electron microscopes. Elemental distribution for copper and nickel in the fuel electrode and the nickel plating were obtained by EDS technique. Cell fuel electrode in contact with the copper slurry showed the absence of the discrete copper layer and densification (Figure 3.7) and cracking of the existing zirconia skeleton (Figure 3.8). Fuel electrode which was not in contact with the copper slurry, however, remained porous and maintained the original structure (Figure 3.9). EDS analysis of the fuel electrode in contact with the copper slurry showed the presence of copper throughout the thickness of the fuel electrode. Copper was also found present in the existing nickel plating over the cell interconnection layer. For cell from cell test 578, the copper layer present over the interconnection showed localized diffusion in the nickel felt.

\subsubsection{Densification of the fuel electrode:}

Polished cross sections of the fuel electrode (in contact with the copper bonding layer) shows densification and reduction in the porosity as shown in Figure 3.7 whereas the fuel electrode layer away from the copper bonding layer contact shows no change in the micro-structure and porosity. Reduction in the porosity of the fuel electrode and densification of the structure is postulated to result from the bulk diffusion of copper from the bond layer into the nickel fuel electrode during the high temperature operation of the cell. Since a large area metallic contact exists between the copper bond layer and the nickel fuel electrode and that the diffusivity of copper in nickel remains higher than the diffusivity of nickel in copper at all temperatures (5), flow of copper takes place in the nickel fuel electrode. Similar scenario exists for the transport of copper in the nickel felt but at much lower flux levels because of limited felt - copper layer contact. 

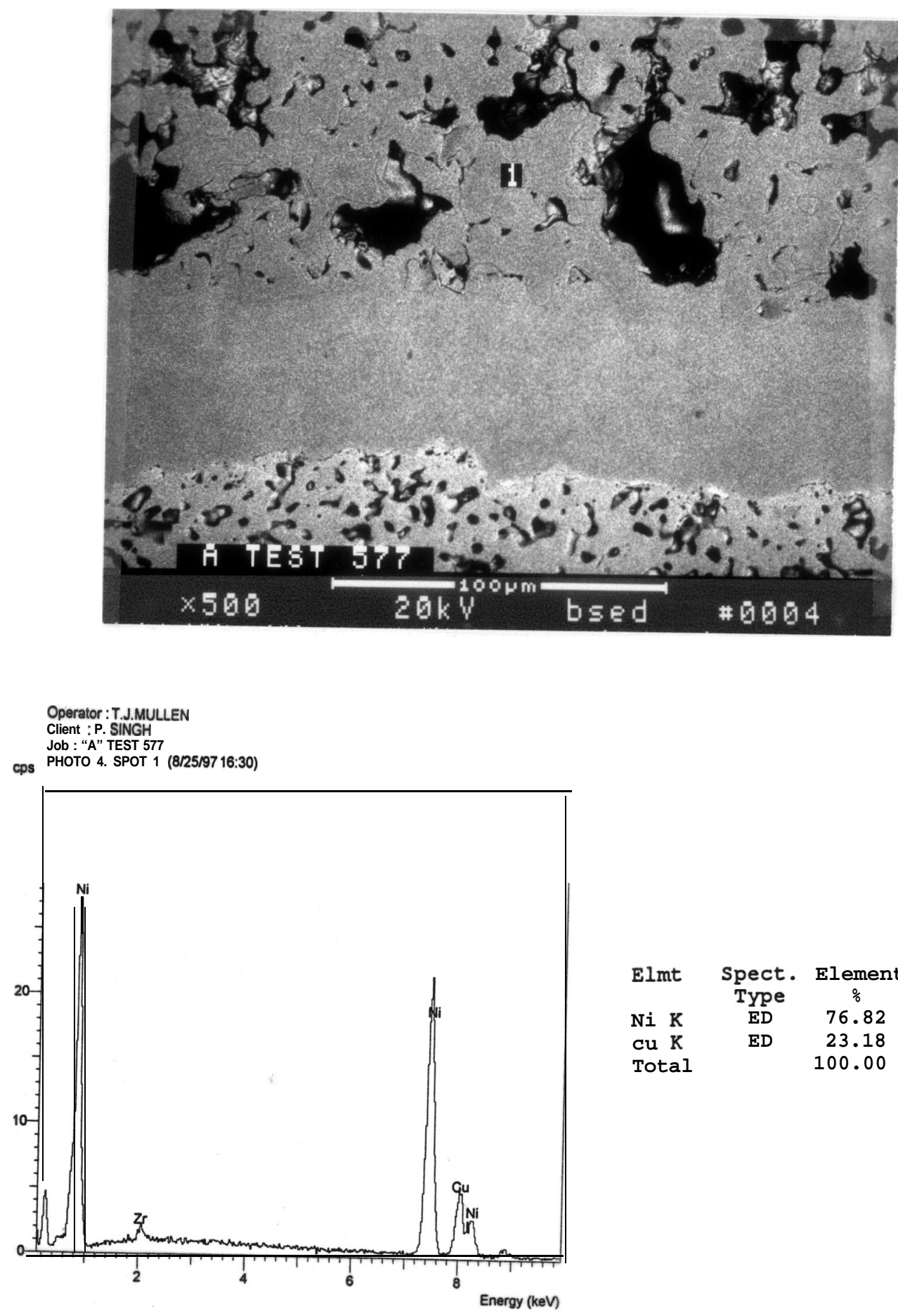

$\begin{array}{lccc}\text { Elmt } & \begin{array}{c}\text { Spect. } \\ \text { Type }\end{array} & \begin{array}{c}\text { Element } \\ \frac{0}{0}\end{array} & \begin{array}{c}\text { Atomic } \\ \frac{8}{8}\end{array} \\ \text { Ni K } & \text { ED } & 76.82 & 78.20 \\ \text { cu K } & \text { ED } & 23.18 & 21.80 \\ \text { Total } & & 100.00 & 100.00\end{array}$

Figure 3.7 - Densification of fuel electrode due to diffusion of copper. 


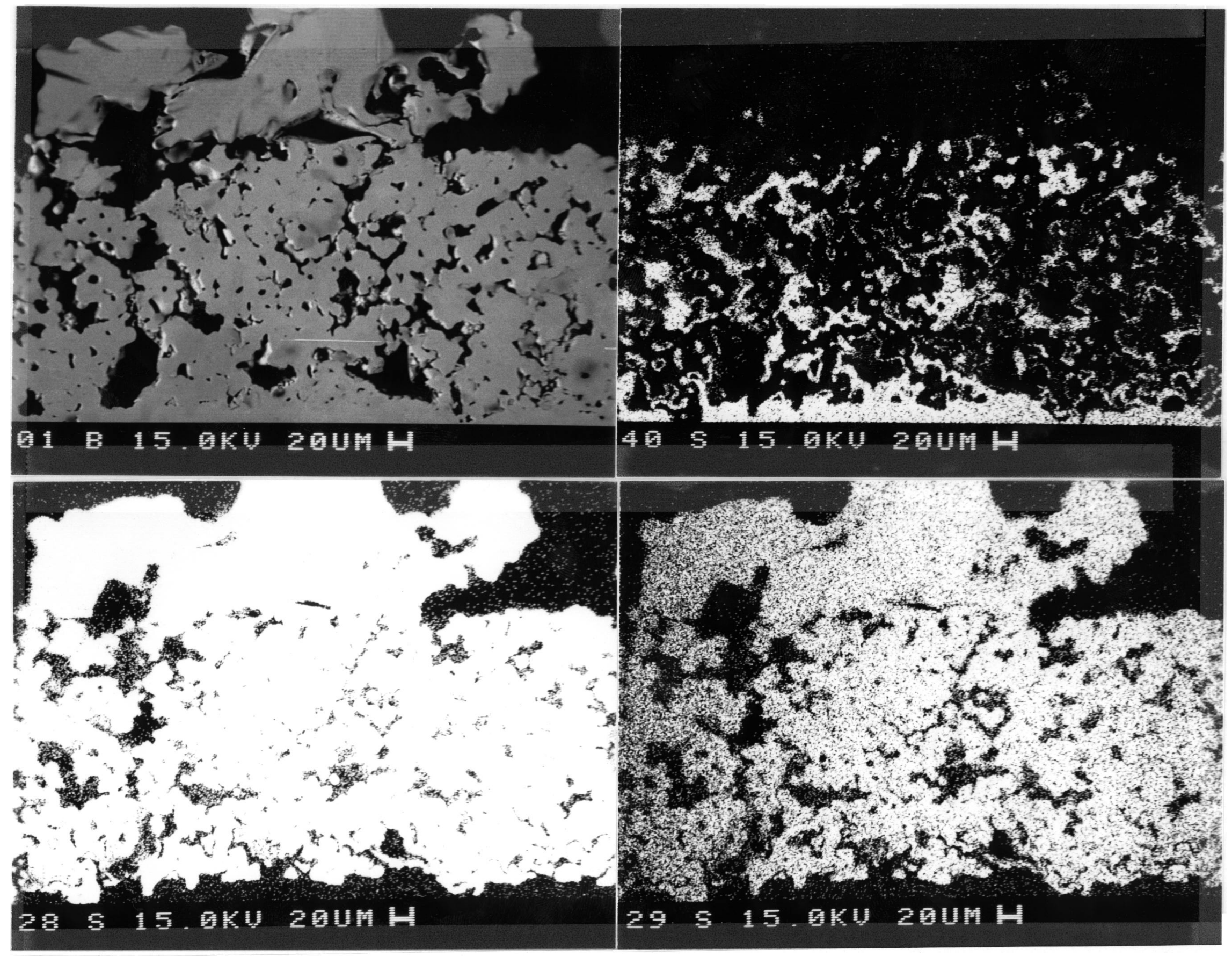

Figure 3.8 - Elemental distribution in the fuel electrode. Fuel electrode shows copper throughout the thickness and an absence of a discrete copper layer. 

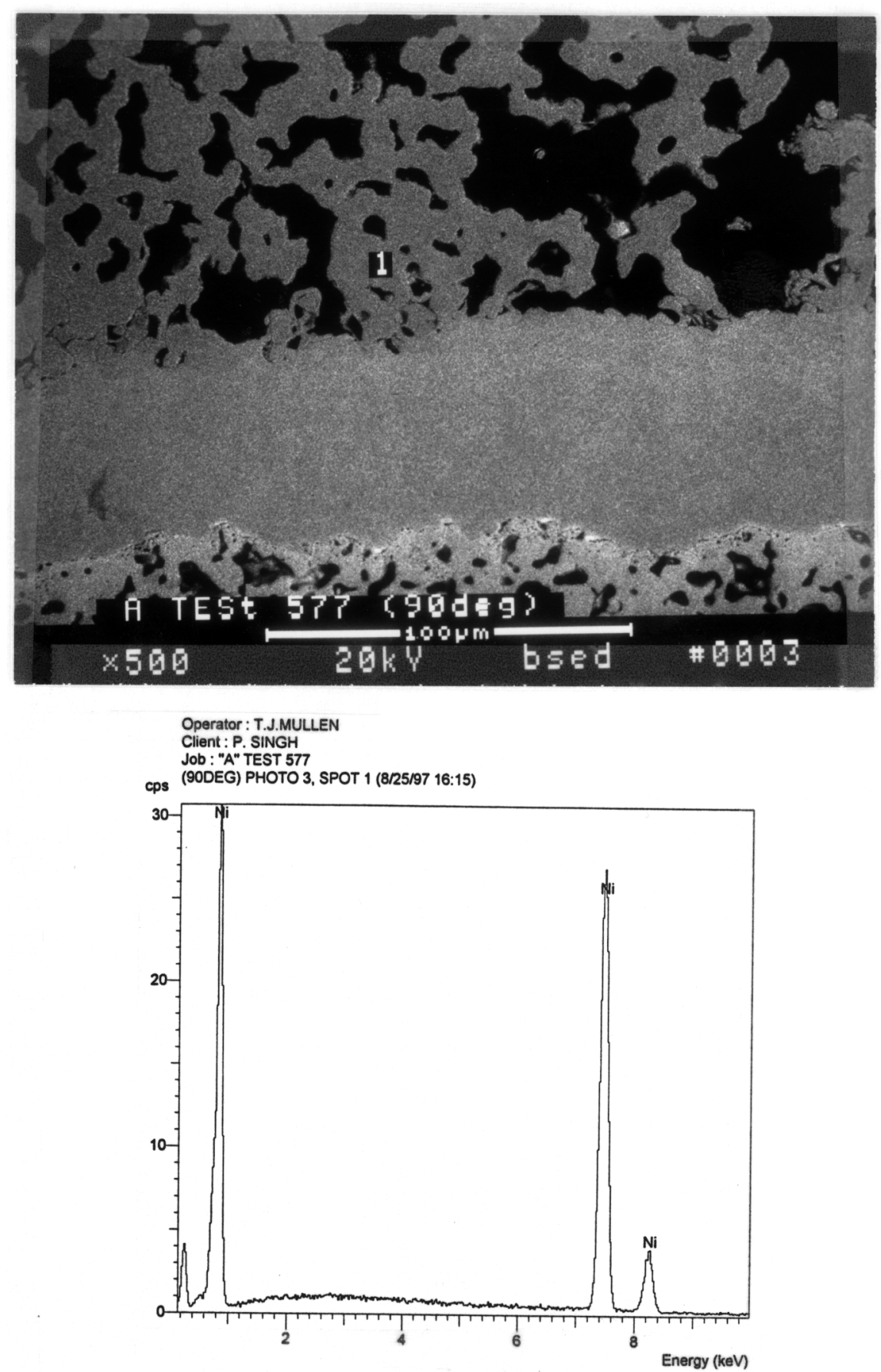

Figure 3.9 - Porous fuel electrode structure obtained at $90^{\circ}$ from the $\mathrm{Cu}$ contact area. 


\subsubsection{Absence of copper bond layer:}

After the completion of the cell test, polished cross sections of the cell assembly showed the absence of the discrete copper bond layer initially present at the fuel electrode - nickel felt and interconnection - nickel felt interfaces. Nickel felts were also easily separated from the cell surfaces indicating the weakening of bond. Loss of copper from the sintering / bonding layer is considered to be due to the preferential migration of copper away from the copper layer into the adjoining nickel containing cell components. Since nickel and copper form a continuous solid solution and that the diffusivity of copper in nickel remains high at the cell operating temperature, copper diffusion in nickel proceeds with time resulting in the depletion of the copper layer. Removal of copper from the interface results in reduced fuel electrode - felt contact and weakening of the bond.

\subsubsection{Increased cell resistance:}

Cell test 578 showed continuous rise in the cell resistance during the electrical test. After the termination of the test, it was observed that the nickel felt bonded to cell interconnection layer was separated from the cell near the closed end. The copper layer over the interconnection appeared porous and had a shiny appearance resembling that of nickel. It is postulated that the copper sintered layer present on the interconnection diffuses in the nickel felt at the felt contacts resulting in loss of material, poor contact and adhesion of the copper layer with the interconnection. Resistance of the cell increases because of the poor contact.

From the above observations, it becomes clear that the copper bond layer present at the fuel electrode - nickel felt and interconnection - nickel felt remains prone to diffusion in the nickel. Migration of copper in the cell components also reduces the component bond strength.

\subsection{CONCLUSIONS}

Based on cell electrical performance and microstructural observations, following conclusions are made: 
(1) Copper sintering / bonding additive diffuses in the cell fuel electrode and interconnection nickel plating. Diffusion of copper in the cell fuel electrode leads to volume expansion and densification of the fuel electrode.

(2) Faster diffusion of copper in nickel leads to bulk transport of copper from the bond layer. This results in loss of copper and the development of porous and weaker interface layer.

(3) Transport of copper from the interconnection surface due to its diffusion in the nickel felt leads to the separation of nickel felt from the interconnection surface. This results in an increase in the cell resistance and performance loss.

\subsection{REFERENCES}

(1) O. Kubaschewski, E. Ll. Evans and C. B. Alcock, "Metallurgical Thermochemistry" Pergamon Press, 1967

(2) M. Hansen, "Constitution of Binary Alloys" Page 601, McGraw Hill Book Company, 1958

(3) Y. S. Touloukian "Thermophysical Properties of High Temperature Solid Materials "Volume 2, Part 1, Page 343, The Macmillan Company

(4) K. Hauffe, "Oxidation of Metals" Page 30, Plenum Press, 1965

(5) D. B. Butrymowicz et al., "Diffusion Rate Data and Mass Transport Phenomena for Copper Systems" Page 193 - 202, International Copper Research Association, Inc. 


\section{AIR IMPURITIES}

\subsection{OBJECTIVES}

The objective of this work was to determine what effects if any high levels of common air pollutants have on SOFC performance. After a review of air pollution data, three impurities were identified which were considered to have a potentially deleterious impact on SOFC performance.

\subsection{BACKGROUND}

The common air pollutants are carbon monoxide (CO), nitrogen dioxide $\left(\mathrm{NO}_{2}\right)$, ozone $\left(\mathrm{O}_{3}\right)$, lead $(\mathrm{Pb})$, sulfur dioxide $\left(\mathrm{SO}_{2}\right)$, and particulates less than $10 \mu \mathrm{m}$ in size. EPA ambient air quality standards for each contaminant are listed in Table 4.1 along with values from some locations where extreme levels were measured during 1996.[1]

Table 4.1 - EPA Regulated Air Pollutants

\begin{tabular}{|c|c|c|c|c|}
\hline \multirow{2}{*}{\multicolumn{2}{|c|}{ Pollutant / Measurement }} & \multirow{2}{*}{$\begin{array}{c}\text { EPA } \\
\text { Standard }\end{array}$} & \multicolumn{2}{|r|}{1996 Extremes } \\
\hline & & & level & location \\
\hline $\mathrm{CO}$ & $8 \mathrm{hr}$ average & $9 \mathrm{ppm}$ & $17.5 \mathrm{ppm}$ & Los Angeles County, CA \\
\hline & $1 \mathrm{hr}$ average & $35 \mathrm{ppm}$ & & \\
\hline $\mathrm{NO}_{2}$ & annual arithmetic mean & $0.053 \mathrm{ppm}$ & & \\
\hline $\mathrm{O}_{3}$ & $1 \mathrm{hr}$ average & $0.12 \mathrm{ppm}$ & $0.239 \mathrm{ppm}$ & San Bernardino County, CA \\
\hline $\mathbf{P b}$ & quarterly average & $1.5 \mu \mathrm{g} / \mathrm{m}^{3}$ & & \\
\hline $\mathrm{SO}_{2}$ & annual arithmetic mean & $0.03 \mathrm{ppm}$ & & \\
\hline & $24 \mathrm{hr}$ average & $0.14 \mathrm{ppm}$ & $0.230 \mathrm{ppm}$ & Hawaii Volcanos Nat'l Park \\
\hline & $3 \mathrm{hr}$ average & $0.50 \mathrm{ppm}$ & & \\
\hline Parti & $\begin{array}{l}\text { tes }<\mathbf{1 0} \boldsymbol{\mu m} \\
\text { annual arithmetic mean }\end{array}$ & $50 \mu \mathrm{g} / \mathrm{m}^{3}$ & & \\
\hline
\end{tabular}


Carbon monoxide as an impurity in the air will be oxidized to $\mathrm{CO}_{2}$ probably before it reaches the air electrode and therefore should not present a problem to the SOFC. Nitrogen dioxide is not expected to have any effects on the air electrode either, although it may be reduced at the air electrode/electrolyte interface. Ozone is expected to be reduced just as $\mathrm{O}_{2}$ and be a source of $\mathrm{O}^{2-}$ ions. Airborne lead could be a problem if concentrations were high enough, but this is very unlikely.

Sulfur dioxide, on the other hand, could initiate some chemical altering of the air electrode. Lanthanum oxysulfate, $\mathrm{La}_{2} \mathrm{O}_{2} \mathrm{SO}_{4}$ is known to be stable to almost $1400^{\circ}$ C. [2] Steele has indicated that $\mathrm{La}_{2} \mathrm{O}_{2} \mathrm{SO}_{4}$ can form from the reaction of $\mathrm{SO}_{2}$ and air electrode material at $\mathrm{SO}_{2}$ concentrations as low as 1 ppm.[3]

Additionally some components of air which are not considered pollutants may have a considerable effect on the air electrode and consequently the SOFC as a whole. The effect of water vapor on the SOFC is not known. It is believed that water vapor may react with the air electrode to form hydrates with lanthanum or manganese. Water vapor may also enhance the reaction of other contaminants such as $\mathrm{SO}_{2}$ with the air electrode. Neither of these possible effects has been examined. All previous cell tests have used a dedicated or house supply of compressed air. The compressors used in these systems incorporate intercooling which condenses almost all of the water vapor from the air resulting in dry air being sent to the cells.

In coastal areas the air can be filled with aerosol particles produced by wave action. These aerosol particles can contain high levels of sodium and magnesium chlorides and other dissolved salts. Any reaction of chlorine with the air electrode could be a problem since $\mathrm{LaCl}_{3}$ exists in the liquid phase between 860 and $1000^{\circ} \mathrm{C}$. Sodium and magnesium could potentially react with the air electrode to form low melting temperature compounds as well. Chlorides from aerosol particles may also have a significant effect on the metal components of the SOFC generator's air delivery system. 


\subsection{EXPERIMENTAL}

A single cell test was conducted at $1000^{\circ} \mathrm{C}$ and $250 \mathrm{~mA} / \mathrm{cm}^{2}$ using a $2.2 \mathrm{~cm}$ diameter, $50 \mathrm{~cm}$ active length cell. The SOFC used in the testing had previously been tested as a part of a two cell test article where it had operated for 3574 hours and completed 39 thermal cycles. That test was ended when a crack developed in the second cell as a result of thermal shock. The remaining good cell was considered an excellent candidate for impurities testing since it was already broken in and had long history of operation under normal (no impurities) conditions.

The air impurities testing was conducted in two parts. In the first part the effects of water vapor and sulfur dioxide were examined, and in the second part the effects of sea water mist were examined. In between these two tests the cell was operated without any impurities for approximately 200 hours.

For the gaseous impurities testing, the air delivery system was modified as shown in Figure 4.1 so that the impurity gases could be introduced. Sulfur dioxide was added by combining the house air with gas from a cylinder containing $0.1 \% \mathrm{SO}_{2}$ in air. Water vapor was introduced by bubbling the house air through water at $47^{\circ} \mathrm{C}$. At this temperature the gas mixture leaving the bubble contained $89 \%$ air and $11 \% \mathrm{H}_{2} \mathrm{O}$. When switching from dry air to humidified air, the flow of air through the mass flow controller was reduced so that the net flow rates of dry air and humidified air would be the same. The $\mathrm{SO}_{2} /$ air mixture was introduced to the line downstream from the bubbler so that the $\mathrm{SO}_{2}$ would not become dissolved in the liquid water.

Thermodynamic calculations were performed to better estimate the conditions ( $\mathrm{SO}_{2}$ concentrations) under which lanthanum oxysulfate formation could 


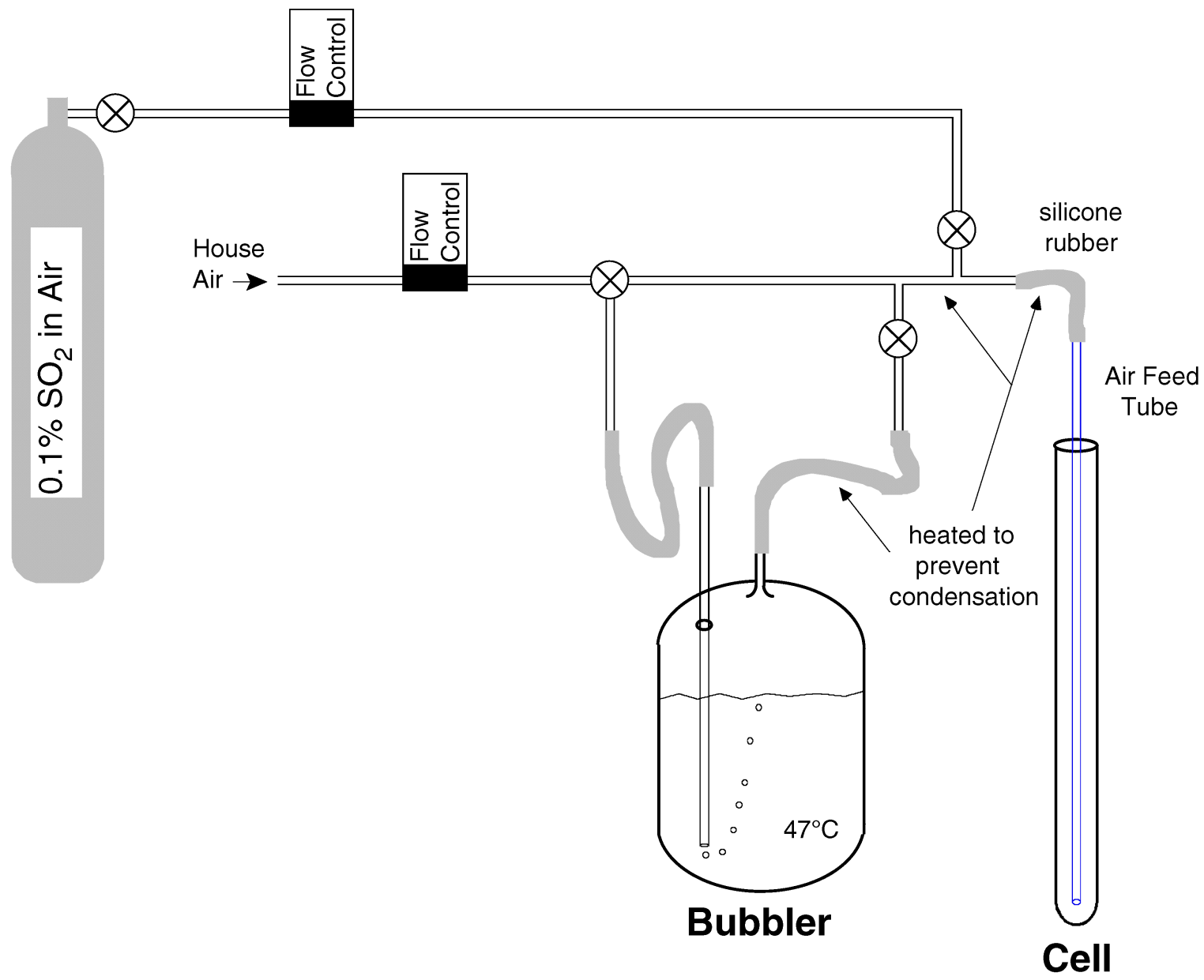

Figure 4.1 - Illustration of the air delivery system used for testing with gaseous impurities. 
occur in the air electrode. At $1000^{\circ} \mathrm{C}$ the most stable manganese oxides are $\mathrm{Mn}_{3} \mathrm{O}_{4}$ and $\mathrm{Mn}_{2} \mathrm{O}_{3}$ with higher pressures $\left(\mathrm{pO}_{2}>1.3 \mathrm{~atm}\right)$ favoring $\mathrm{Mn}_{2} \mathrm{O}_{3}$. The proposed reaction for lanthanum oxysulfate formation is

$$
2 \mathrm{LaMnO}_{3}+\mathrm{SO}_{2}+1 / 3 \mathrm{O}_{2} \Rightarrow \mathrm{La}_{2} \mathrm{O}_{2} \mathrm{SO}_{4}+2 / 3 \mathrm{Mn}_{3} \mathrm{O}_{4}
$$

The free energy change for this reaction was calculated to be $-85.2 \mathrm{~kJ} / \mathrm{mol}$ at $1000^{\circ} \mathrm{C}$. ${ }^{[4-5]}$ Taking $\mathrm{pO}_{2}=0.21 \mathrm{~atm}$, the equilibrium $\mathrm{pSO}_{2}$ was calculated to be $5.36 \mathrm{x}$

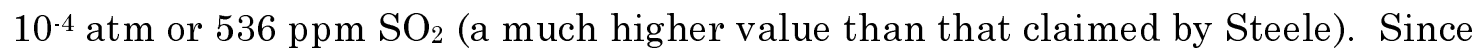
this is one to two orders of magnitude higher than any conceivable operating environment for an SOFC generator, testing conditions were restricted to more realistic extremes.

During the gaseous impurities testing, the cell was operated under 4 different conditions:

- Humidified Air (89\% Air, 11\% water vapor)

- Dry Air with 0.25 ppm $\mathrm{SO}_{2}$

- Humidified Air with 0.25 ppm $\mathrm{SO}_{2}$

- Dry Air with 2 ppm $\mathrm{SO}_{2}$

The water vapor concentration used in the humidified air was equivalent to $100 \%$ relative humidity at $47^{\circ} \mathrm{C}\left(117^{\circ} \mathrm{F}\right)$. The sulfur dioxide concentrations were chosen to represent the highest repeating concentrations recorded in the United States during 1996 and a level more than 14 times greater than the EPA's ambient air quality limit.

Sea water mist testing was designed to evaluate worst case operating conditions for SOFC generators in coastal or off-shore locations. Two methods of introducing sea water mist into the air feed were used. In the first method air was passed through a bubbler filled with 8 to 10 liters of sea water (Figure 4.2). Because of the high flow rate for air, the bubbling process was relatively violent creating significant amounts of aerosol particles. Each day the bubbler would be taken out of 


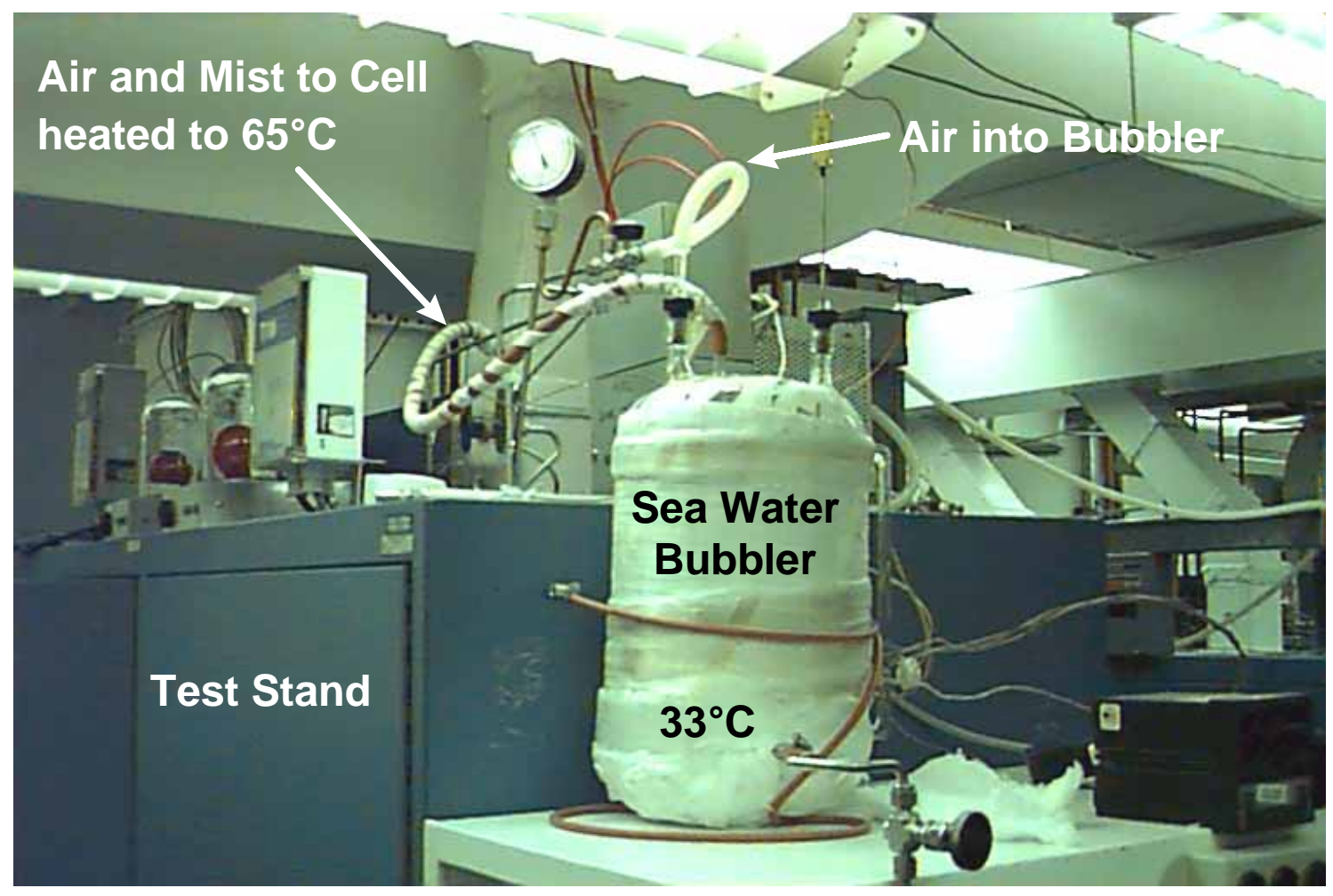

Figure 4.2 - Photograph showing set up of the seawater bubbler. 
the air line and weighed. The amount of aerosol transmitted to the cell was determined by measuring the total water loss and subtracting the calculated water loss due to evaporation. Afterward appropriate amounts of deionized water (to replace evaporated water) and sea water (to replace aerosol loss) were added to the bubbler, and the bubbler was put back in the air line. With the bubbler temperature maintained at $33^{\circ} \mathrm{C}$ and a constant air flow of $6.9 \mathrm{slpm}$, the water lost due to evaporation in a 24 hour period was calculated to be $417 \mathrm{~g}$. The actual water lost in 24 hours varied between 500 and $600 \mathrm{~g}$ indicating that 17 to $30 \%$ of the total water loss was in the form of aerosol particles.

The second method of introducing sea water mist used a modified ultrasonic humidifier. The humidifier was able to deliver a greater amount of aerosol droplets than the bubbler. However, in general it was less reliable. It was difficult to maintain the proper level of sea water above the transducer due to small fluctuations in the air line pressure. Larger pressure transients could produce air leaks in the humidifier which jeopardized the cell. As a result, the humidifier was only used during working hours when it could be closely monitored.

The sea water used in the testing was prepared from two sources. Initially a salt mixed according to ASTM Standard D-1141-52 (Table 4.2) was used at a concentration of $42 \mathrm{~g}$ salt/liter of solution. Later, the sea water was prepared using Instant Ocean ${ }^{\circledR}$ synthetic sea salt (Aquarium Systems, Mentor, Ohio).

Table 4.2 - Composition of Sea Salt Used in Sea Water Mist Experiments

\begin{tabular}{|l|c|l|c|}
\hline \multicolumn{1}{|c}{ Salt } & \multicolumn{2}{c|}{$\begin{array}{c}c \\
\text { Amount }\end{array}$} & \multicolumn{1}{c|}{ Amoult } \\
\hline \hline $\mathrm{NaCl}$ & $58.490 \%$ & $\mathrm{NaHCO}_{3}$ & $0.477 \%$ \\
\hline $\mathrm{MgCl}_{2} \cdot 6 \mathrm{H}_{2} \mathrm{O}$ & $26.460 \%$ & $\mathrm{KBr}$ & $0.238 \%$ \\
\hline $\mathrm{Na}_{2} \mathrm{SO}_{4}$ & $9.750 \%$ & $\mathrm{H}_{3} \mathrm{BO}_{3}$ & $0.071 \%$ \\
\hline $\mathrm{CaCl}_{2}$ & $2.765 \%$ & $\mathrm{SrCl}_{2} \cdot 6 \mathrm{H}_{2} \mathrm{O}$ & $0.095 \%$ \\
\hline $\mathrm{KCl}$ & $1.645 \%$ & $\mathrm{NaF}$ & $0.007 \%$ \\
\hline
\end{tabular}


Once the air left the bubbler or ultrasonic humidifier it traveled through a silicone rubber hose approximately $1 \mathrm{~m}$ before reaching the alumina air feed tube. As in previous testing with humidified air, this length of hose was maintained at $65^{\circ} \mathrm{C}\left(150^{\circ} \mathrm{F}\right)$ in order to prevent condensation of water in the line.

\subsection{RESULTS AND DISCUSSION}

The gaseous impurities appeared to have only minor effects on SOFC performance. A voltage versus time plot is given in Figure 4.3 for the first 2200 hours of testing. On start up of the test, the cell quickly returned to the level at which at which it had been operating previously as a two cell test, $602 \mathrm{mV}$ at 304 $\mathrm{mA} / \mathrm{cm}^{2}$. The various test conditions are indicated on the plot and are listed in Table 4.3.

Table 4.3 - Duration of Testing with Different Impurities

\begin{tabular}{|l|c|}
\hline \multicolumn{1}{|c|}{ Impurity } & Duration \\
\hline \hline Humidified Air (89\% Air, 11\% water vapor) & 78 hours \\
\hline Dry Air with 0.25 ppm SO 2 & 142 hours \\
\hline Humidified Air with $0.25 \mathrm{ppm} \mathrm{SO}_{2}$ & 622 hours \\
\hline Dry Air with 2 ppm SO 2 & 309 hours \\
\hline Sea Water Mist & 503 hours \\
\hline
\end{tabular}

The change over to humidified air at 143 hours was accompanied by an approximately $10 \mathrm{mV}$ drop in cell voltage. Some of this drop appears to be associated with interfacial polarization. The addition of $11 \%$ water vapor to the air lowers the $\mathrm{pO}_{2}$ from 0.208 atm to 0.185 atm which corresponds to a $3 \mathrm{mV}$ decrease in Nernst potential. A similar dilution using nitrogen rather than water vapor produced a $4 \mathrm{mV}$ drop in cell voltage. Subsequent testing with sea water mist found that the actual water vapor content in the air could have been as much as $20 \%$ higher due to pick-up of aerosol droplets. In that case the $\mathrm{pO}_{2}$ would have been $0.180 \mathrm{~atm}$, but the change in Nernst potential for a $0.208 \mathrm{~atm}$ to $0.180 \mathrm{~atm}$ change in $\mathrm{pO}_{2}$ would still be no more than $4 \mathrm{mV}$. The presence of water vapor clearly has a 


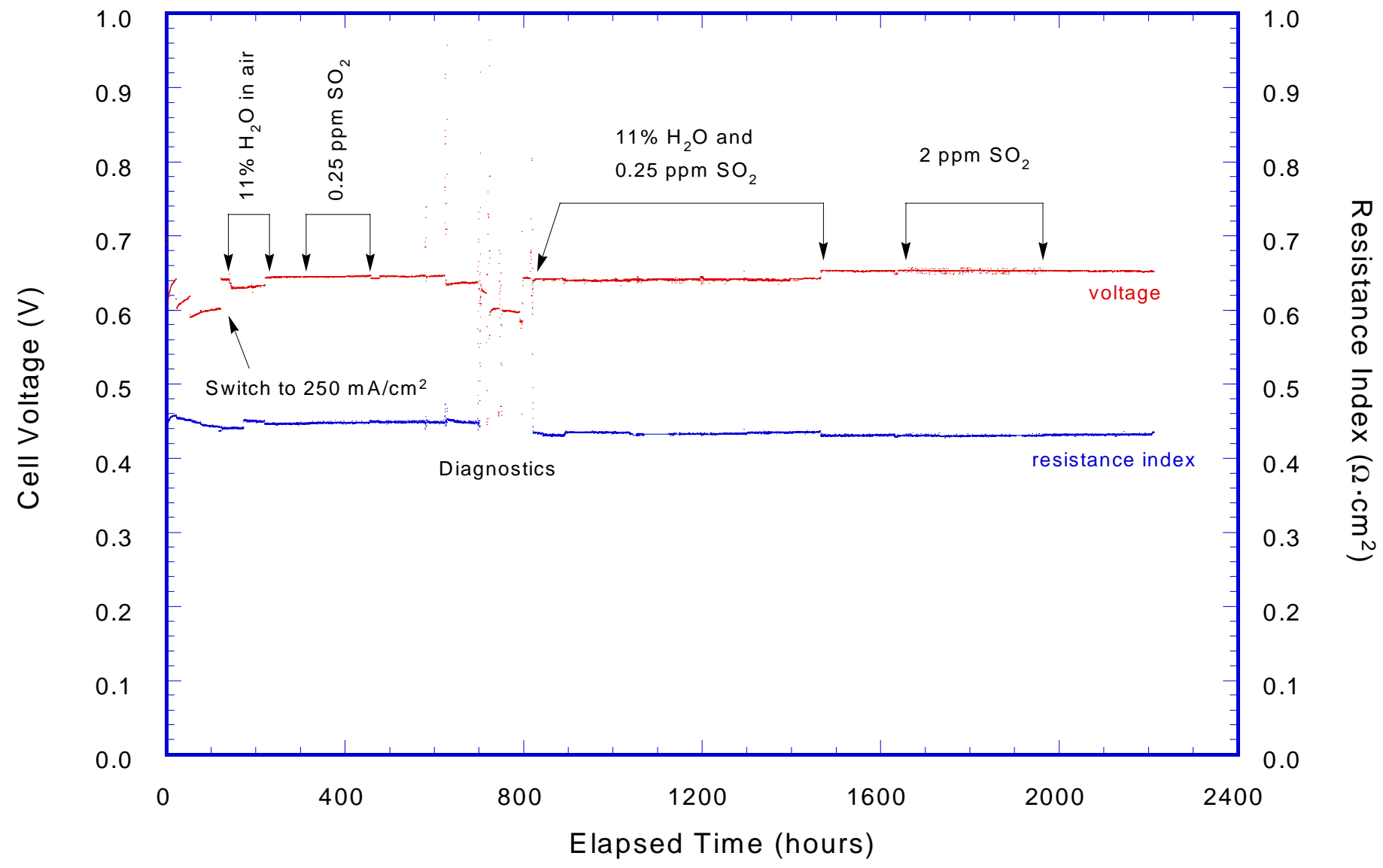

Figure 4.3- Cell voltage and resistance data from testing with gaseous impurities (0 to 2200 hours elapsed time). 
negative effect on interfacial polarization. Voltage-current plots are shown in Figure 4.4 comparing cell operation on dry air with operation on humidified air. On return of the cell to dry air operation, the $10 \mathrm{mV}$ voltage loss was immediately and completely recovered. The slight rise in cell voltage with time during the humidified air testing was attributed to break-in of the test article.

When the cell was operated on dry air with $0.25 \mathrm{ppm}$ sulfur dioxide, no change in voltage was observed as the impurity appeared to have no effect on cell performance. Testing with $0.25 \mathrm{ppm} \mathrm{SO}_{2}$ and humidified air was conducted for a longer period of time to examine the effect of the combination of impurities and to see if longer times were required to observe the effects of any reaction of $\mathrm{SO}_{2}$ with the air electrode. Once again a voltage drop of about $10 \mathrm{mV}$ occurred when humidified air was introduced. The cell voltage, however, remained steady after the initial drop and regained the lost voltage once it was returned to operation on dry air. Analysis of the exhaust gas leaving the cell did detect the presence of $\mathrm{SO}_{2}$ in appropriate concentrations, but at $0.25 \mathrm{ppm} \mathrm{SO}$ does not appear to affect cell performance. Further testing was conducted with air containing 2.0 ppm $\mathrm{SO}_{2}$, but again this had no noticeable effects on cell performance. The noise seen in the voltage data during this segment of the test is an artifact of the continuous resistance measurement.

The effect of water vapor on cell performance was also observed during testing with sea water mist in the air supply. Voltage versus time data for the second half of the test are shown in Figure 4.5. In this case the voltage drops associated with the sea water mist were 5 to $6 \mathrm{mV}$. The smaller value was due to the lower water vapor content of the air (5\% rather than the previous $11 \%)$. The periodic spikes in the voltage data are due to brief open circuit operation while the sea water bubbler was being weighed and refilled. The cell operated for a total of 503 hours on air containing sea water mist. During that time a total of $3300 \mathrm{~g}$ of aerosol droplets (132 g of sea salt) were introduced into the air feed. 


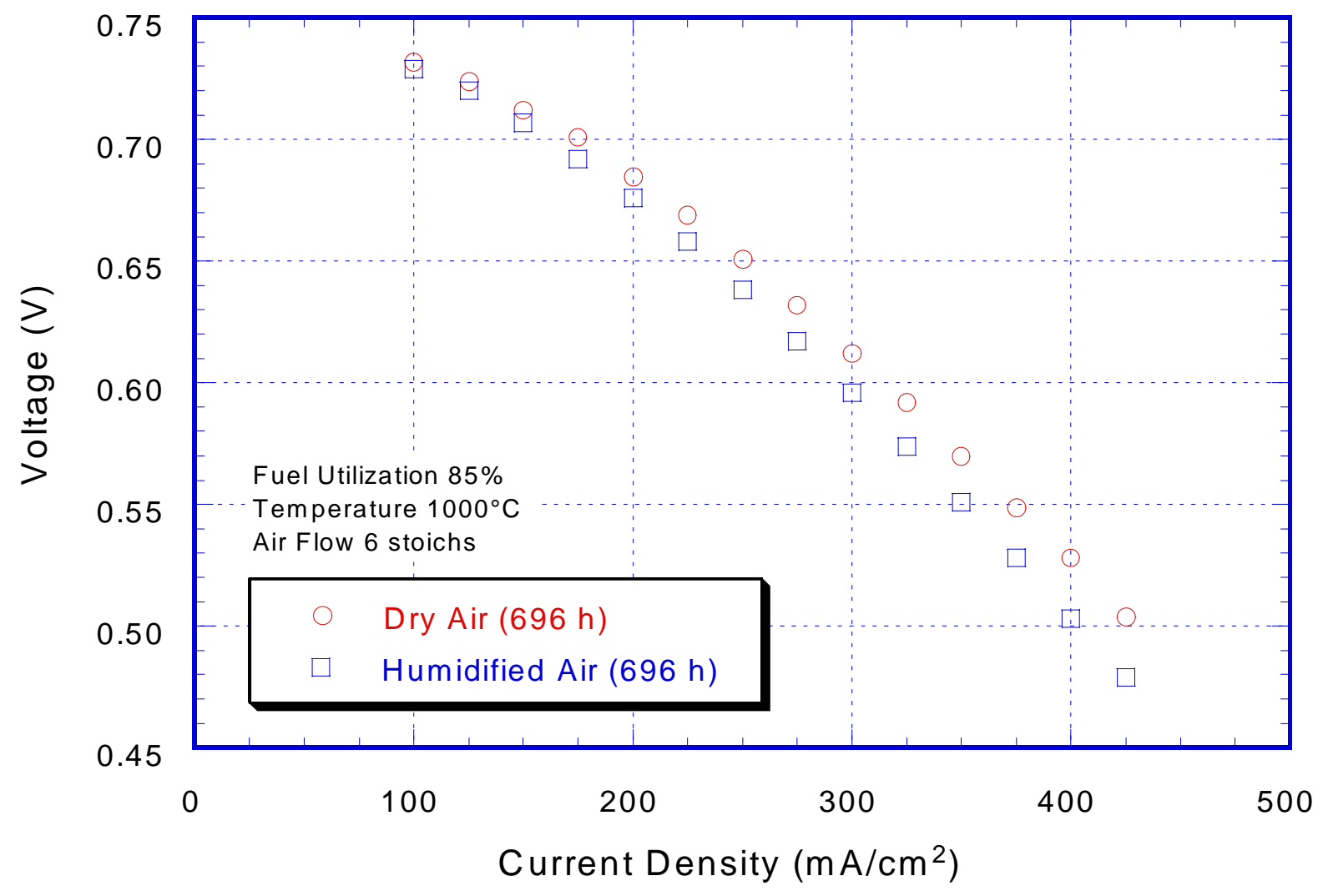

Figure 4.4 - Voltage versus current density curves comparing cell performance on dry and humidified air. 


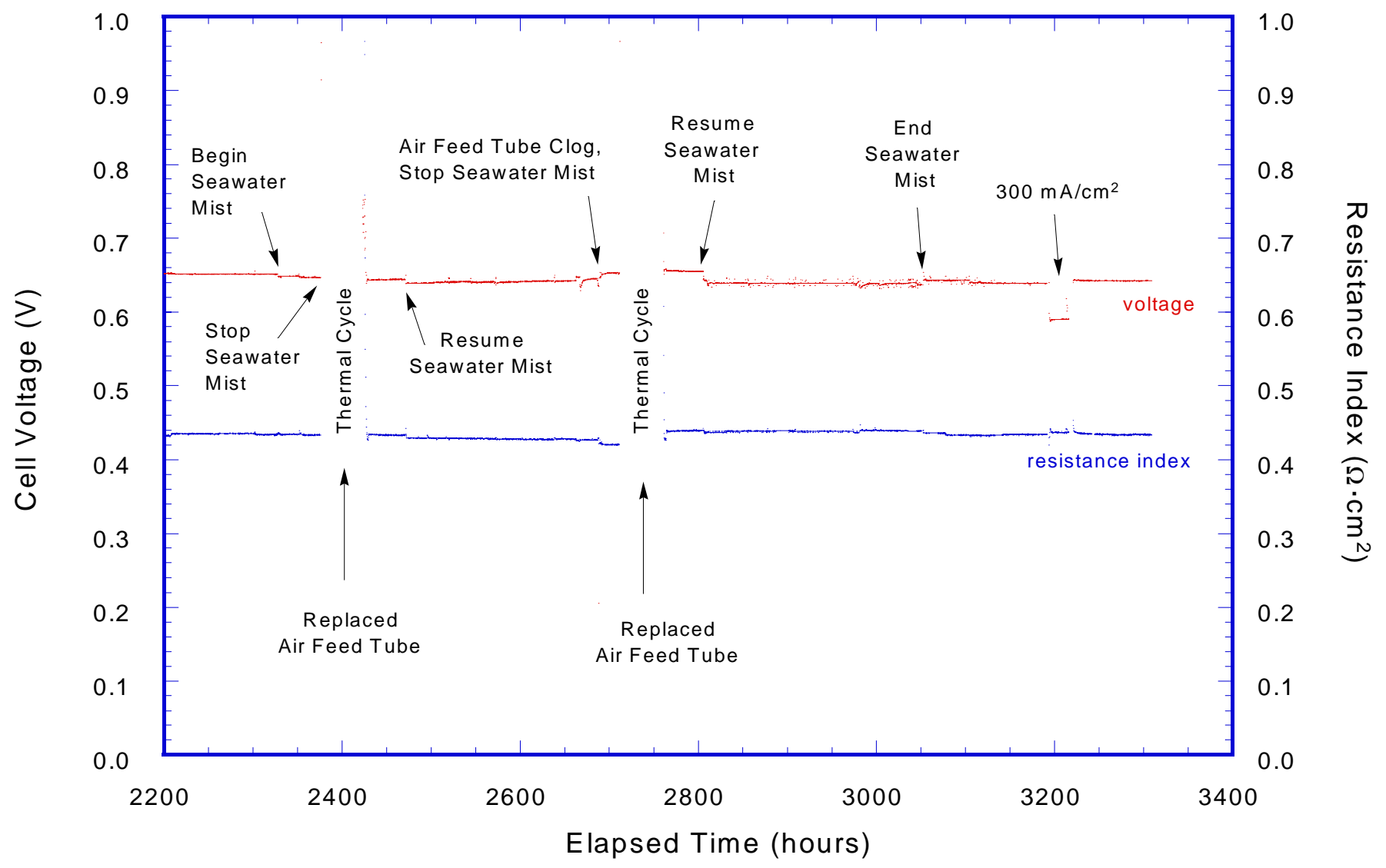

Figure 4.5 - Cell voltage and resistance data from testing with air containing sea water mist (2200 to 3300 hours elapsed time). 
Twice during the sea water mist testing the cell was cooled, and the air feed tube was replaced. The first change was at $\sim 2375$ hours elapsed time and was not necessitated by operational problems. The air feed tubes normally used in cell testing are significantly smaller in diameter than those used in generators and are frequently reused for more than one test. Because of the potential for the air feed tube to become clogged with salt, it was decided to replace the small diameter feed tube with one of the type used in the EDB/ELSAM generator. This new tube was weighed prior to restart of the test so that any salt deposition could be quantified. The second cooling and air feed tube replacement was at $\sim 2725$ hours, and this time it was necessitated by an apparent clog in the air feed tube.

Inspection of the air feed tube found that the top $8 \mathrm{~cm}$ of the tube was filled with salt. This salt appears to have originally been deposited on the inside wall of the silicone rubber hose which connects the bubbler (or ultrasonic mister) with the air feed tube. The salt apparently broke off the wall of the hose and fell into the air feed tube as there was a jump in line pressure rather than a gradual rise. Inspection of the rubber hose found $\sim 3 \mathrm{~g}$ of salt deposited on its inside wall in addition to the $1.5 \mathrm{~g}$ of salt in the air feed tube. The silicone rubber hose was cleaned, and the air feed tube was replaced. At the time that the clog developed the ultrasonic mister was being used to supply sea water mist to the cell. It is believed that the build up of salt in the silicone rubber hose was caused by the use of the ultrasonic mister. When the bubbler is used, the air carrying the aerosol droplets is already saturated with water vapor due to the bubbling process. With the ultrasonic mister this is not the case. Here dry air is passed through the column where the aerosol droplets are produced. As the air traveled through the silicone rubber hose, a significant portion of the water in the droplets must have evaporated resulting in the deposition of salt on the walls of the hose.

A voltage versus current curve was generated during sea water mist testing and is compared to a dry air curve in Figure 4.6. Slightly lower performance is seen during operation with sea water mist. A more interesting comparison is between 


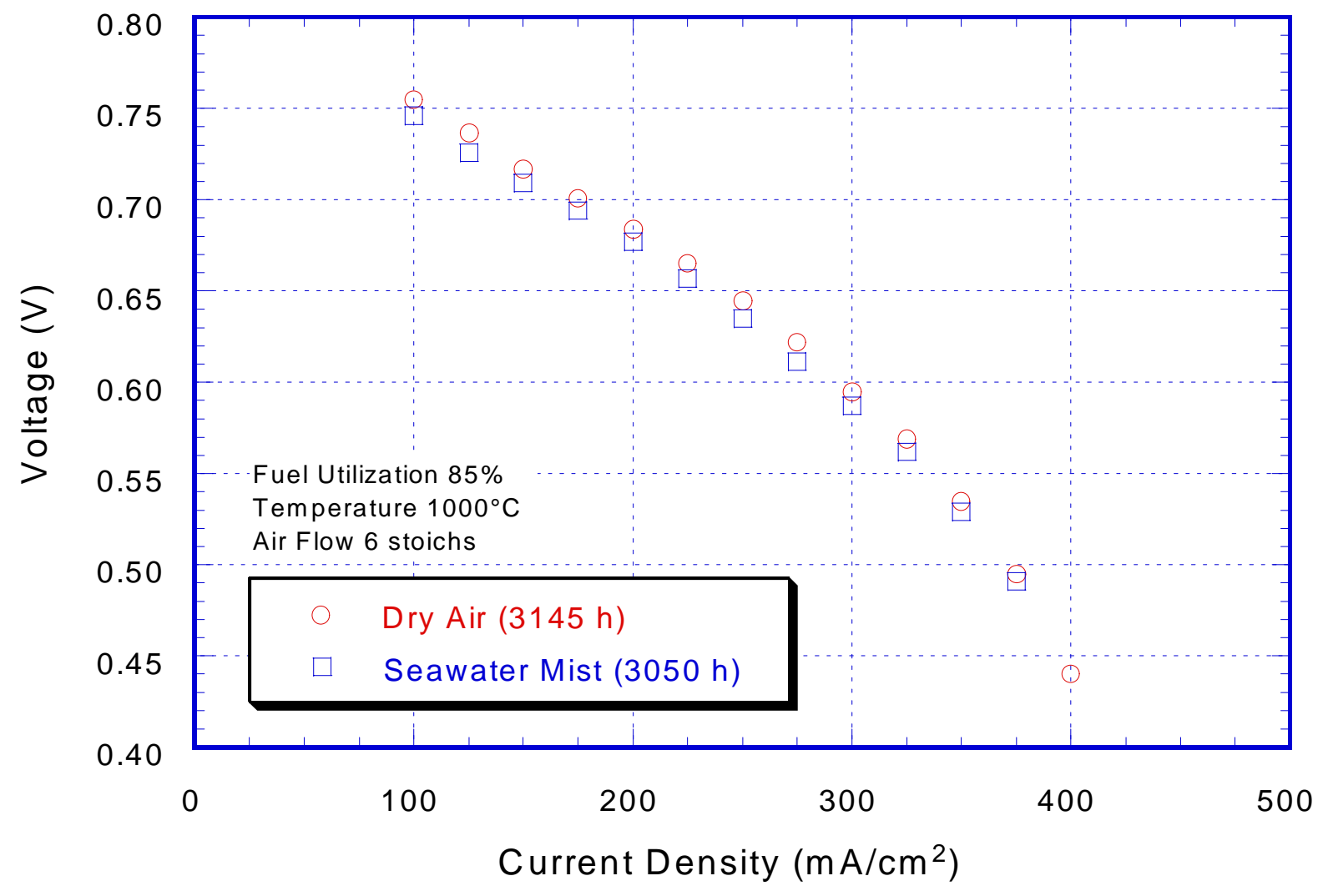

Figure 4.6 - Voltage versus current density curves comparing cell performance on air containing sea water mist with that of dry air. 
the dry air curves taken at 696 and 3145 hours elapsed time (Figure 4.7). While there is only a small difference in the two curves at $250 \mathrm{~mA} / \mathrm{cm}^{2}$, a significant performance loss can be seen in the latter curve at higher currents.

At the end of the test, inspection of the cell by borescope found no more than $1 \mathrm{~g}$ of salt on the interior surface of the cell, the vast majority ( $>90 \%)$ of the salt must have been absorbed into the air electrode pores or transported out of the system. Salt deposits observed on the exterior of the air feed tube (Figure 4.8) strongly support transport out of the test article. Microcharacterization of the cell found evidence of reaction on the inside surface of the air electrode. Reaction was mostly confined to the closed end of the cell and to the first $40 \mu \mathrm{m}$ at the inside diameter. Towards the middle and the open end of the cell the air electrode appeared normal. The chemistry of the reaction products was surprising. Two phases were observed: one primarily composed of silicon, calcium, and lanthanum and another containing mainly manganese, aluminum, silicon and magnesium. Neither aluminum nor silicon were components of the sea salt. The aluminum obviously originated in the aluminum oxide air feed tube. The source of silicon would have had to have been the silicone rubber tubing which connected the bubbler with the air feed tube.

The reaction products on the inside surface of the air electrode, however, were too insignificant to explain the performance losses shown in Figure 4.7. Examination of the air electrode/electrolyte interface found a more likely cause: a thin layer of silicon rich material at the interface. This layer was also confined primarily to the closed end of the cell and tapered to nonexistent at the open end of the cell (Figure 4.9). What role the impurities testing played in the transport of this silicon is not clear, and several possibilities exist. One possibility is that the impurities played no role at all and that the heating of the silicone rubber tubing led to the silicon transport. Another possibility is that the sulfur dioxide or the sea salt could have initiated some minor corrosion of the rubber, and certainly all of these 


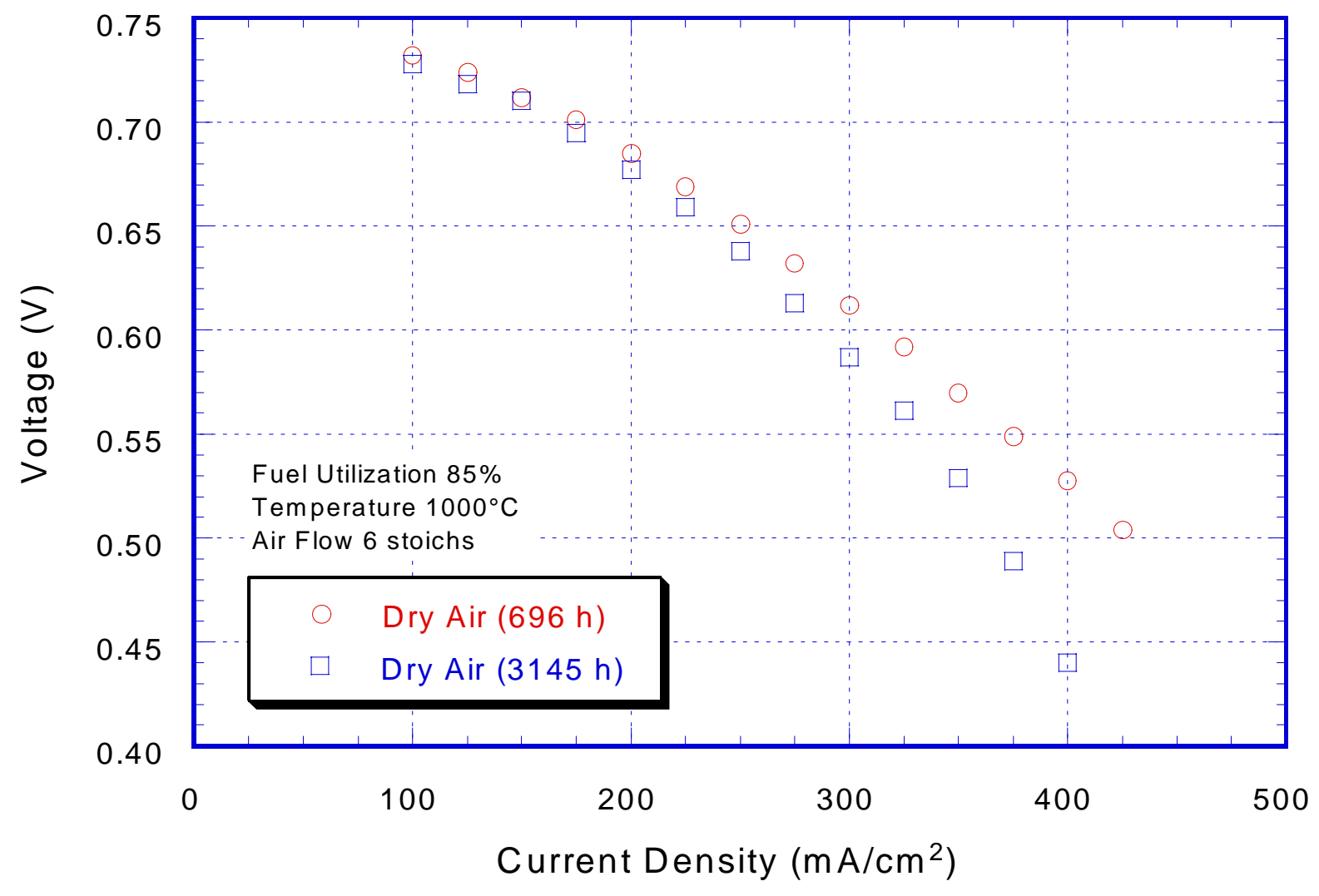

Figure 4.7 - Voltage versus current curve comparing cell performance on dry air early in the test to that at the end of the test. 


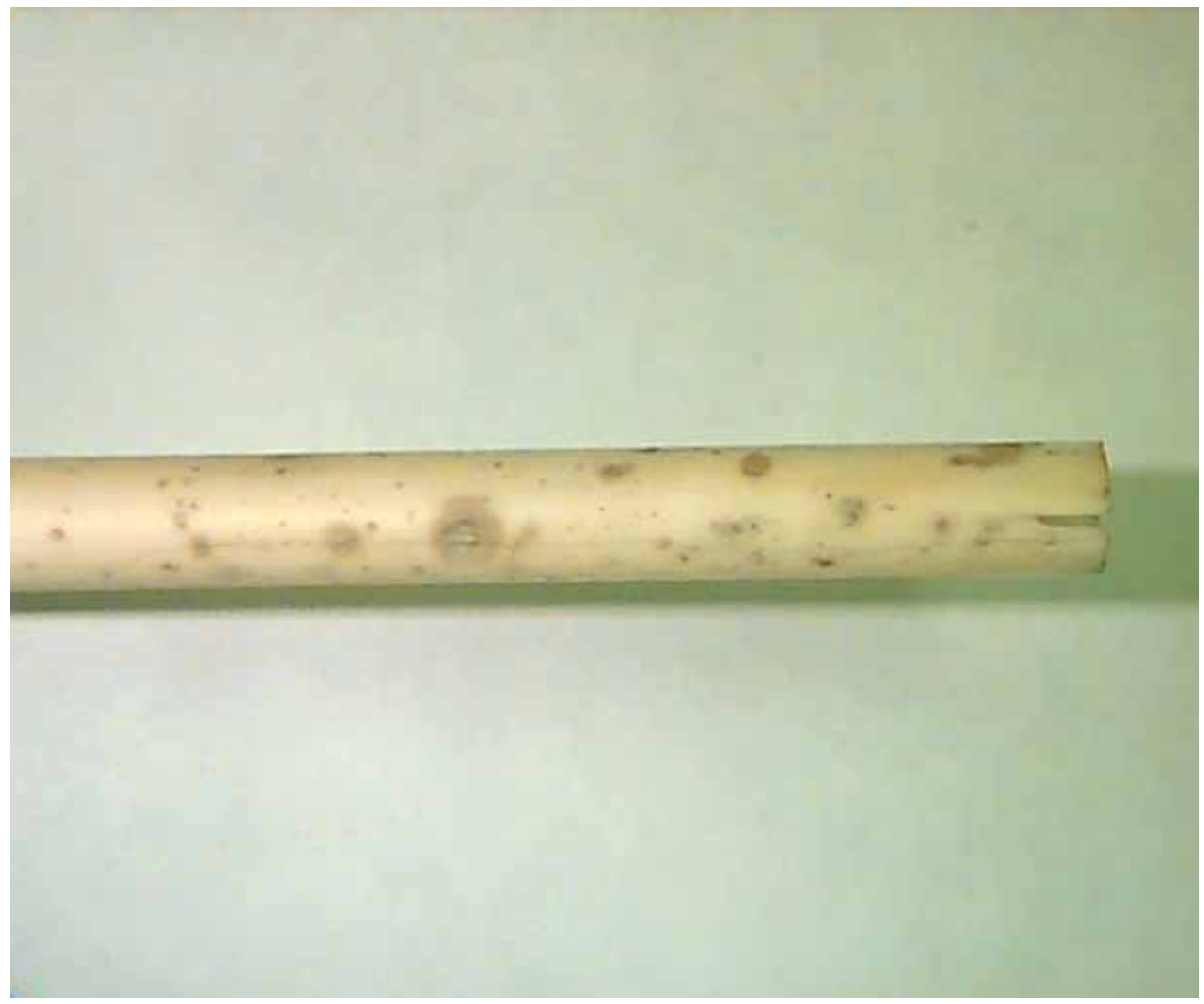

Figure 4.8 - Photograph showing air exit region of the air feed tube used during sea water mist testing. Notch at end of tube was cut prior to use. 


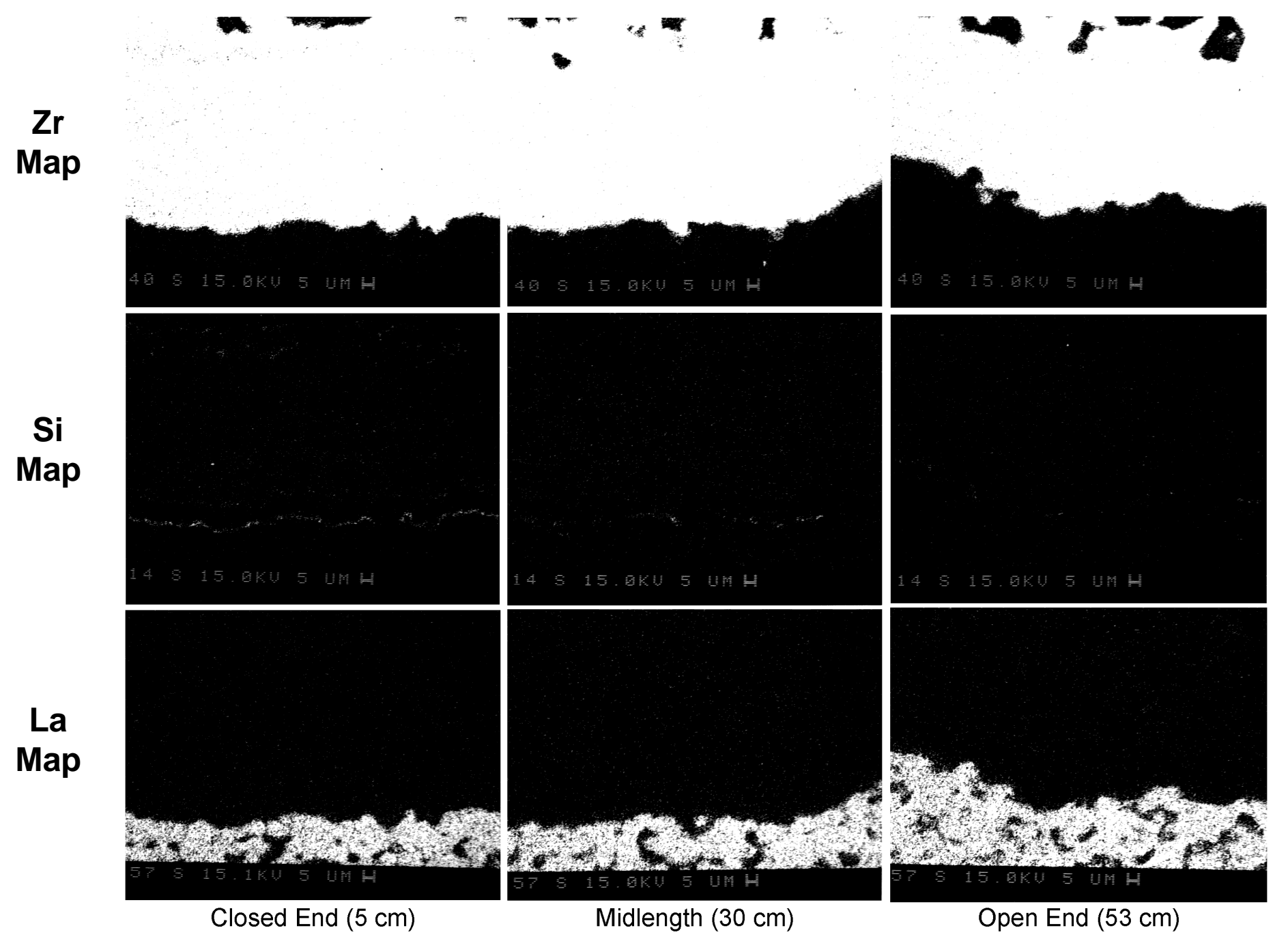

Figure 4.9- EBMA elemental maps for $\mathrm{Zr}$, $\mathrm{Si}$, and $\mathrm{La}$ showing the air electrode/electrolyte interface at three different positions on the cell. Values in cm refer to actual distance to the cell closed end. 
factors could have contributed together. It is also interesting that silicon was found on the inside surface of the air electrode and at the air electrode/electrolyte interface but not elsewhere within the air electrode. Whatever the case, the source of the silicon contamination (silicone rubber tubing) is not used in SOFC generators. Therefore the performance loss shown in Figure 4.7 would not have occurred in an actual SOFC generator.

\subsection{CONCLUSIONS}

- Operation of the SOFC on humidified air does effect performance. The voltage loss resulting from the use of air containing $11 \%$ water vapor was $10 \mathrm{mV}$.

- The effect of water vapor is instantaneous, and on returning to dry air operation the SOFC recovers all lost voltage.

- No voltage loss was observed during operation with $\mathrm{SO}_{2}$ impurities at concentrations up to $2.0 \mathrm{ppm}$ (>14 times the U.S. E. P.A. ambient air quality limit).

- The SOFC is tolerant of operation in air containing sea water mist. Voltage losses can be completely attributed to water vapor. Most all of the salt passes through the cell with only minimal deposition at the extreme inside diameter of the air electrode.

- The performance loss which occurred during the impurities testing was the result of silicon contamination from a silicone rubber hose used in the air delivery system and was not due to the impurities themselves.

\subsection{REFERENCES}

[1] U. S. Environmental Protection Agency, National Ambient Air Quality Standards.

[2] M. W. Nathans and W. W. Wendlandt, "The Thermal Decomposition of the Rare Earth Sulphates," Journal of Inorganic and Nuclear Chemistry, 24 869879 (1962).

[3] B. C. H. Steele, Personal Communication, (1996).

[4] N. Fukatsu, N. Shidawara, and Z. Kozuka, Journal of the Electrochemical Society, 132 2258-2263. 
[5] R. K. Dwivedi and D. A. R. Kay, Metallurgical Transactions B, 15B 523-528. 